\title{
NAFLD Preclinical Models: More than a Handful, Less of a Concern?
}

\author{
Yvonne Oligschlaeger * and Ronit Shiri-SverdloviD \\ Department of Molecular Genetics, School of Nutrition and Translational Research in Metabolism (NUTRIM), \\ Maastricht University, Universiteitssingel 50, 6229 ER, Maastricht, The Netherlands; \\ r.sverdlov@maastrichtuniversity.nl \\ * Correspondence: yvonneoligschlaeger@ziggo.nl
}

Received: 14 January 2020; Accepted: 5 February 2020; Published: 8 February 2020

\begin{abstract}
Non-alcoholic fatty liver disease (NAFLD) is a spectrum of liver diseases ranging from simple steatosis to non-alcoholic steatohepatitis, fibrosis, cirrhosis, and/or hepatocellular carcinoma. Due to its increasing prevalence, NAFLD is currently a major public health concern. Although a wide variety of preclinical models have contributed to better understanding the pathophysiology of NAFLD, it is not always obvious which model is best suitable for addressing a specific research question. This review provides insights into currently existing models, mainly focusing on murine models, which is of great importance to aid in the identification of novel therapeutic options for human NAFLD.
\end{abstract}

Keywords: NAFLD; mouse models; multifactorial disease; translational value

\section{Introduction}

Due to excess intake of fat- and/or sugar-enriched diets and a lack of exercise, overweight and obesity are currently a major and continuously growing public health concern. Strongly associated with the increasing trend in obesity is the metabolic syndrome (MetS), in which disturbed lipid homeostasis and metabolic inflammation are taking the lead. Besides type 2 diabetes (T2D) and cardiovascular diseases, MetS increases the risk of developing non-alcoholic fatty liver disease (NAFLD), the most prevalent chronic liver disease worldwide [1]. The spectrum of NAFLD ranges from benign simple steatosis [2] to steatohepatitis (NASH) and end-stage liver diseases. If steatosis is not managed in time, resident liver cells (e.g., Kupffer and hepatic stellate cells) become activated and immune cells (mainly macrophages) infiltrate the liver, a condition defined as NASH. This progressive form of NAFLD [3] can further trigger hepatocyte damage with/without fibrosis and increase the risk of cirrhosis [4] and hepatocellular carcinoma (HCC) [5]. In contrast to alcoholic liver disease- and viral hepatitis-induced HCC, NASH-related HCC is currently the most rapid growing indication for liver transplant in HCC patients [6].

Obviously, there is an urgent need for a reliable 'humanized' model that displays a liver phenotype that is identical to human disease, with macrovesicular steatosis, lobular inflammation, hepatocellular ballooning (including Mallory-Denk bodies), and fibrosis as predominant features. Subsequently, an optimal NAFLD model should have the ability to further progress to advanced fibrosis, cirrhosis, and ultimately HCC. Moreover, it should encompass MetS-related characteristics, such as obesity, disturbed lipid, glucose and insulin metabolism, as well as systemic inflammation. So far, using a wide variety of preclinical models, considerable efforts have recently been made to better understand the pathogenesis of human NAFLD and/or related clinical questions. However, none of these models resemble the complete human NAFLD spectrum, including related metabolic features that recapitulate this chronic liver disease. For instance, several models, exposed to various dietary compositions, have 
broadened our knowledge with regard to NAFLD progression, in particular early-onset low-grade inflammation. Alternative models (genetic or chemically-induced) provided insights into fibrotic features of human NAFLD, one of the most important predictors of human NASH progression [7]. Other models have been more suitable for testing therapeutic interventions in the context of NAFLD/NASH. Nevertheless, there are still significant unmet needs with regard to non-invasive diagnostic methods, therapeutic target identification, and drug development, which implies the need for robust preclinical models [8]. In the current Review, we will provide an update on existing preclinical NAFLD models. This Review focuses on rodents, mainly on mouse models, which are relatively low in costs and therefore allow for studying metabolic and genetic drivers of NAFLD/NASH within a considerable time frame. Moreover, these models serve as an important and well-controlled tool for preclinical drug testing in a multisystemic environment.

\section{Insights into Available Preclinical Models for Non-alcoholic Fatty Liver Disease}

A wide variety of dietary, genetic, chemically-induced, and/or other rodent models ([8-16]) have greatly advanced our understandings on NAFLD pathophysiology, as will be discussed in the following sections (see also Figure 1, Table 1).

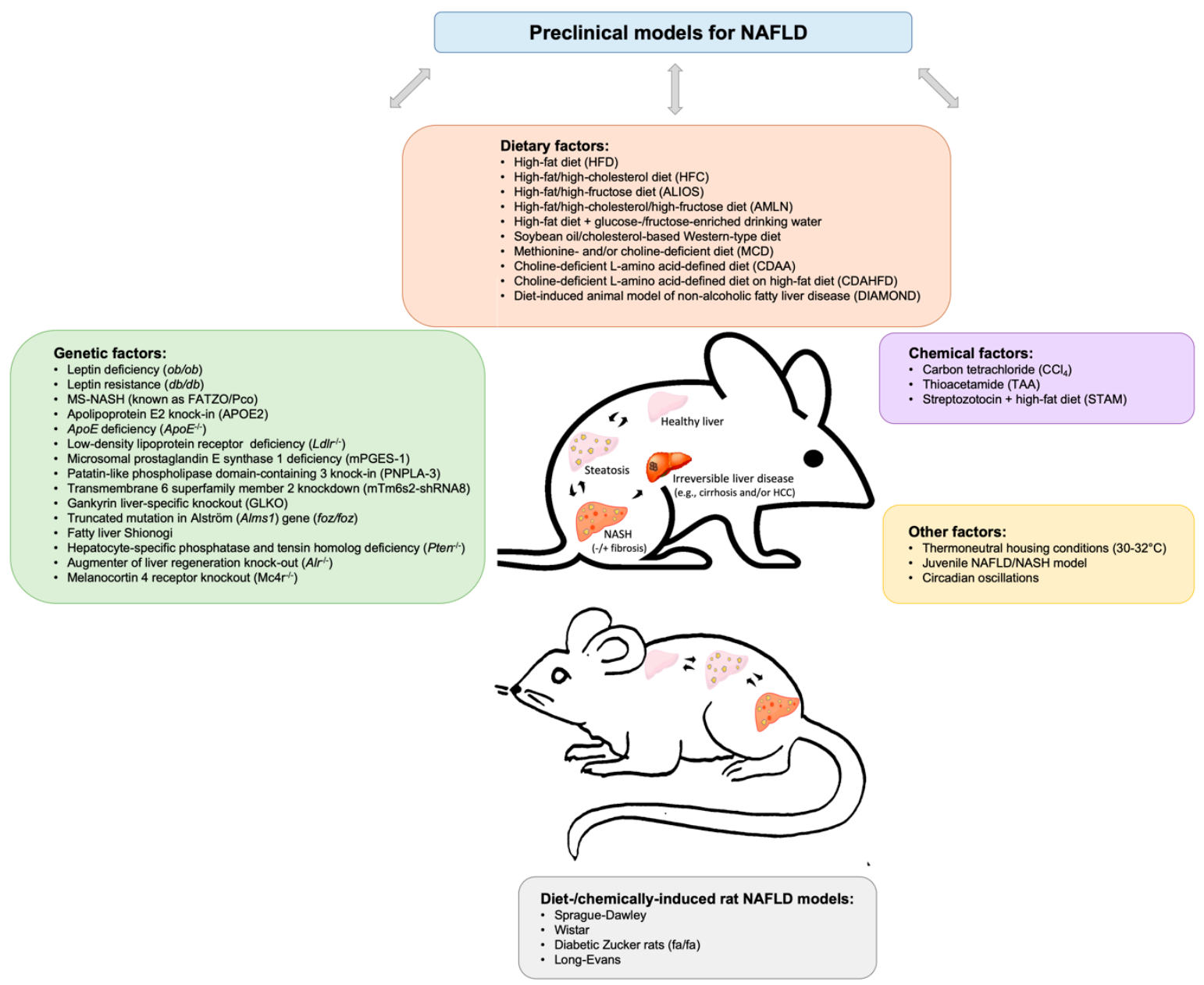

Figure 1. Brief schematic overview of existing preclinical models involving a variety of dietary, genetic, chemical, and other factors to study non-alcoholic fatty liver disease (NAFLD). 


\subsection{Dietary Murine Models}

Diet-induced obesity is known to be the most common risk factor for NAFLD in humans [17]. The experimental NAFLD/NASH models are often based on overnutrition, a condition that can be induced by means of diets varying in macronutrient composition, amongst others.

One of the simplest ways of disturbing lipid metabolism, inducing steatosis and moderate NASH, is by the administration of a regular high-fat diet (HFD; 60\% fat, 20\% proteins, 20\% carbohydrates) $[18,19]$. For instance, feeding wild-type C57BL/6 mice a HFD for 10-12 weeks resulted in phenotypic changes such as hyperlipidemia, hyperinsulinemia, and glucose intolerance [19,20]. Despite hepatic steatosis, inflammatory cell infiltration was not present until 19 weeks of HFD intake [19]. While after long-term (34-36 weeks) HFD feeding, significant increases in circulating liver enzyme levels, i.e., alanine aminotransferase (ALT) and aspartate aminotransferase (AST) were observed [19], these mice showed only minor signs of inflammation and fibrosis [21], even after prolonged administration up to 50 weeks [19]. Yet, after chronic feeding (80 weeks) of HFD, which mimics lifetime HFD consumption and enables proper design of treatment options, Velázquez et al. [17] demonstrated that mice displayed obesity and insulin resistance. In addition, these mice were shown to develop NAFLD features, including hepatic steatosis, cell injury, portal and lobular inflammation, hepatic ER stress, as well as fibrosis [17]. In line with Chen et al. [22], which showed a deterioration in NAFLD when germ-free mice were inoculated with the Firmicutes phyla, they also found increases in the Firmicutes phyla in response to prolonged HFD [17]. Though intestinal permeability was not measured in this study, these data pointed towards diet-induced gut-microbial dysbiosis [17], a well-known microbial event that has been previously observed in NAFLD patients [23]. Yet, it is unclear whether a similar but shorter dietary intervention would also provide insights into NAFLD progression [17].

In contrast to regular HFD, the atherogenic diet, composed of $1.25 \%$ cholesterol plus $0.5 \%$ cholate, resulted in increased plasma and liver lipid levels and was shown to induce NASH with hepatocellular ballooning in a time-dependent manner from 6-24 weeks [24]. Notably, the addition of a high-fat component exacerbated the histologic severity of NASH, and resulted in hepatic insulin resistance, oxidative stress, and activation of hepatic stellate cells [24]. Exposure to HFD containing 0.1-2.0\% cholesterol (HFC) [25,26] for seven months in murine models, such as wild-type C57BL/6 mice, resulted in the development of obesity, hepatomegaly, hepatic steatosis, and varying degrees of steatohepatitis [27].

Due to the variability in disease onset and limited development of fibrosis, a novel so-called Amylin Liver NASH (AMLN) model was generated [28]. This model covers a high-fat/high-fructose $(40 \% / 22 \%)$ diet containing trans-fatty acids ( $18 \%)$ and high-cholesterol ( $2 \%)$, thereby better resembling the Western-type diet and subsequent development of NASH features. Remarkably, only after 26-30 weeks of feeding an AMLN diet, wild-type C57BL/6 developed marked steatosis, moderate lobular inflammation and hepatocellular ballooning [29]. However, when obese leptin-deficient $o b / o b$ mice were fed a similar AMLN diet for 12 weeks, mice displayed an accelerated and more pronounced metabolic NASH phenotype as compared to wild-type C57BL/6 [29]. Indeed, it is well-known that $o b / o b$ mice, which carry a homozygous mutation in the leptin gene that protect it from binding to its receptor, are susceptible to insulin resistance and T2D, thus being predisposed to metabolic features resembling NAFLD [30]. Yet, spontaneous progression from simple steatosis to NASH and hepatic fibrosis is rather prevented in these mice [31], pointing towards the need of a second stimulus.

More recently, according to the FDA-ban on trans-fats as food additives [32], another obesogenic trans-fat-free diet substituted with saturated fat (palm oil) was explored [33]. This so-called Gubra Amylin NASH (GAN) diet has a nutrient composition and caloric density (40\% high-fat, 22\% high-fructose $2 \%$ high-cholesterol) similar to AMLN diet. Upon feeding $o b / o b$ mice GAN diet for 16 weeks, animals displayed biopsy-confirmed liver lesions with features of fibrotic NASH. While these features were similar to AMLN-fed $o b / o b$ mice, GAN-fed $o b / o b$ mice showed a more pronounced weight gain and increased adiposity. In contrast, wild-type C57BL/6 mice required a prolonged feeding period (28 weeks) of GAN diet to induce consistent fibrotic NASH. However, compared to AMLN diet, 
GAN-fed wild-type mice had significantly greater body weight gain. Altogether, obesogenic GAN diet induces hallmarks of fibrotic NASH in both models [33], suggesting its suitability for preclinical therapeutic testing against NASH.

Administering an alternative fast-food-like nutritional regime based on high-fat/high-fructose/high-cholesterol $(41 \% / 30 \% / 2 \%)$ was also shown to induce NASH in various genotypes [34]. These models included wild-type C57BL/6, ob/ob mice as well as KK- $\mathrm{A}^{\mathrm{y}}$ [35] mice, the latter carrying a mutation in the Agouti gene that increases its susceptibility to human NAFLD-like metabolic alterations [36]. Relevantly, Abe et al. [34] showed that $o b / o b$ mice under these conditions displayed more pronounced NAFLD activity score, fibrosis progression, obesity and hyperinsulinemia compared to the other models. Given that the metabolic, histologic, and transcriptomic features observed in $o b / o b$ mice were similar to human NASH, this model may be further explored as a potential preclinical tool to discover novel drugs for NASH [34].

Relevantly, Henkel et al. [37] explored the impact of long-term exposure (20 weeks) with a high-caloric (43\%) Western-type diet composed of soy-bean oil (high n-6-PUFA, 25g/100g) and 0.75\% cholesterol. In contrast to cholesterol-free HFD [38], dietary cholesterol in soybean oil resulted in increased Kupffer cell activation and oxidative stress as well as hepatic steatosis, ballooning, inflammation and fibrosis in wild-type C57BL/6 [37], which closely resembles clinical NASH features. In line, when mice were fed an alternative high-caloric (45\%) cholesterol-free HFD (composed of lard $(21 \mathrm{~g} / 100 \mathrm{~g}) /$ soy-bean oil $(3 \mathrm{~g} / 100 \mathrm{~g}) / 5 \%$ fructose in drinking water), only mild steatosis and no signs of hepatic inflammation and fibrosis were observed [37]. Thus, in agreement with previous studies $[25,26,38-40]$, these findings indicate that the supplementation of dietary cholesterol triggers experimental hepatic inflammation and fibrosis [37].

Other dietary variants were explored by Montandon et al. [41], comparing the high-fat atherogenic diet $(60 \%$ fat plus $1.25 \%$ cholesterol and $0.5 \%$ cholic acid) versus the commonly used methionine/choline-deficient diet (MCD). In line with others [24,42], wild-type C57BL/6 mice fed a cholesterol/cholate-rich diet showed increases in hepatic cholesterol and free fatty acids, while MCD mice predominantly accumulated triglycerides in their livers [41]. Strikingly, MCD caused a reduction in liver weights, whereas atherogenic diet did not [41]. Moreover, MCD increased hepatic damage, lobular inflammation, lipogranulomas, tissue fibrosis, and liver enzymes compared to mice fed a cholesterol/cholate-rich diet. In addition, transcriptional analyses revealed a dysregulation in extracellular matrix remodeling and hepatic stellate cell activation in response to MCD, but not an atherogenic diet [41]. Altogether, these data pointed towards a more severe form of NASH in MCD mice [41], which was in line with previous studies showing that MCD triggered extensive hepatic inflammation in rats [43] and mice [44-46] within a very short time frame. To overcome the lack of severe hepatic fibrosis often observed in preclinical models, mice are commonly fed MCD [47] or a diet low in/deficient for choline (CD) [48]. Although CD exacerbated fatty liver [48], MCD resulted in rapid NASH development with severe liver fibrosis within 4-10 weeks, likely as a consequence of reduced VLDL synthesis and hepatic- $\beta$ oxidation [20]. While liver inflammation and elevated circulating liver enzyme levels returned back to normal levels after switching the diet back to control within 16 weeks, fibrosis and CD68-positive macrophages remained present [47].

It is also interesting to note that leptin-resistant $d b / d b$ mice (which carry a mutation in the leptin receptor gene [49] and lack the ability to spontaneously develop hepatic inflammation [35,50]) displayed marked hepatic inflammation and fibrosis in response to feeding an MCD diet for four weeks [45]. These data suggest that, similar to $o b / o b$ mice [31,51], $d b / d b$ mice need a second stimulus to induce NASH [45]. Nevertheless, it is noteworthy that all MCD models rather showed significant reductions in weight, concomitant loss in liver mass and cachexia, as well as low serum levels of insulin, fasting glucose, leptin and triglycerides, and a lack of insulin resistance [12,45,52]. Given that these preclinical observations are opposite to the effects seen in overweight and obese individuals with NAFLD, these data suggest that the use of MCD models as preclinical tools to represent human NAFLD is rather limited [53]. Further, though $o b / o b$ and $d b / d b$ models serve as useful preclinical tools that mimic insulin 
resistance as observed in humans, it should be kept in mind that these mice bear mutations that are not prevalent in obese humans or NASH patients.

Relevantly, compared to the MCD diet, mice on a choline-deficient L-amino acid-defined (CDAA) diet developed a more severe degree of NASH and fibrosis, while not having any signs of weight loss [54]. Yet, only after long-term feeding, i.e., 5-6 months with CDAA diet, wild-type C57BL/6 mice displayed increased plasma lipid levels and HOMA-IR, pointing towards the development of insulin resistance [55]. It is relevant to note that the combination of CDAA with HFD may be capable of catalysing the development of NASH [54], though humanized features of metabolic disturbances will be absent in this model [11,54].

The American lifestyle induced obesity syndrome (ALIOS) diet is also a frequently used diet, in which high fat is combined with fructose-containing drinking water [56]. Compared to high trans-fat diets without additional fructose, these mice showed increased body weight and reduced insulin sensitivity, whereas no alterations in the degree of steatosis or liver transaminase levels were observed [11,56]. Moreover, in response to ALIOS diet, some pro-fibrogenic genes were found to be increased, while fibrosis was not detectable [56]. However, when mice were additionally administered a low weekly dose of intraperitoneal carbon tetrachloride $\left(\mathrm{CCl}_{4}\right)$, these animals were shown to develop progressive stages of human fatty liver disease, ranging from simple steatosis to inflammation, fibrosis, and cancer [57]. Nevertheless, one important limitation of ALIOS is related to its dietary composition, as the amount of trans-fat per kilogram is greater than in commonly used fast foods [56].

Another promising model is the so-called diet-induced animal model of non-alcoholic fatty liver disease (DIAMOND). This model is based on wild-type C57BL/6 mice that were crossed with S129S1/svlmJ, a commonly used model to create mice with targeted mutations. After approximately four months of Western-type diet ( $42 \% \mathrm{kcal}$ fat, $0.1 \%$ cholesterol, $3.1 \mathrm{~g} / \mathrm{L} \mathrm{d}$-fructose, $18.9 \mathrm{~g} / \mathrm{L} \mathrm{d}$-glucose), these mice have shown to recapitulate key physiological and metabolic features of human NASH [58]. However, a limitation of this dietary intervention is the high frequency of HCC development and suppression of cholesterol synthesis, which is substantially different from the human situation [12,58].

While in response to a chow diet, MS-NASH mice [59] (formerly known as FATZO/Pco mice, a cross between wild-type C57BL/6J and obesity-prone AKR/J mice [60]) spontaneously develop obesity [61], feeding these mice a Western-type fructose-supplemented diet resulted in progressive features of NAFLD/NASH [59,62]. Given the concomitant dysregulation in metabolic status, these data point towards a novel tool for studying NAFLD with high translational value.

In summary, the above-described models have provided better insights into NAFLD/NASH pathogenesis. Nevertheless, it is noteworthy that these models failed to consistently achieve the full spectrum of human NASH, thereby limiting its preclinical validity.

\subsection{Genetic Murine Models}

Genetic animal models are essential for unravelling the underlying mechanisms related to the progression of NAFLD. Besides obesogenic $d b / d b$ [45] and $o b / o b$ mice [31,51], other models frequently used to study the total spectrum of human NAFLD and associated complications are based on genetically-modified mice in which the murine ApoE gene is being substituted by the human apolipoprotein E2 (APOE2) gene, referred to as the APOE2ki model [63]. Whereas wild-type C57BL/6 mice only developed simple steatosis in response to HFD, APOE2ki mice also displayed early-stage hepatic inflammation [63]. Yet, it is important to note that the inflammatory response did not persist in these mice [63]. Therefore, it is very likely that APOE2 gene is not the main gene responsible for the development of hepatic inflammation $[25,63]$.

Relevantly, a complete lack of the murine $A p o E$ gene, i.e., ApoE ${ }^{--}$model [64], resulted in hyperlipidemia after feeding these mice a high-fat diet [64]. Yet, under these conditions, mice spontaneously developed atherosclerotic plaques, while lacking humanized lipoprotein profiles [64], which suggests that this model is less suitable for human NAFLD research. 
Remarkably, existing knowledge on the low-density lipoprotein receptor $(L d l r)$, an important gene regulating the transport of non-modified lipids into macrophages, led to a major breakthrough in the field of NASH $[25,63]$. By a complete depletion of the $L d l r$, mice fed a HFC diet for 3-12 weeks were able to resemble lifestyle-induced sustained hepatic inflammation [63]. Moreover, these mice displayed high levels of circulating LDL and low levels of HDL, thus closely mimicking the human lipoprotein profile [63]. Hence, this model is considered a physiological model to investigate early onset of NASH $[25,63]$. While the severity of fibrosis is rather mild, these mice have been shown to develop more fibrosis compared to regular C57BL/6 mice on a similar diet $[25,63]$.

A more recent study investigated the relation between prostaglandin E2 and the severity of $\mathrm{NASH}$, both in a clinical and preclinical context [65]. In general, prostaglandin $\mathrm{E}_{2}$, a member of the prostaglandin family, is known to play an important role during the inflammatory processes $[66,67]$ in diseases such as rheumatoid arthritis and osteoarthritis [68]. However, its exact role in hepatic inflammation remains unknown. Henkel et al. [65] showed that a deficiency in the expression of enzymes responsible for murine prostaglandin E2 synthesis triggered a tumor necrosis factor $\alpha$ $(\mathrm{TNF} \alpha)$-dependent inflammatory response in the liver, thereby increasing the severity of diet-induced murine NASH. However, given that fibrosis and genotype-specific differences in macrophage infiltration were rather absent [65], it is very likely that the timing of feeding intervention (20 weeks) was not optimal to allow for advanced-stages disease development.

Another well-known model is based on a knock-in of the Patatin-like phospholipase domain-containing 3 (PNPLA3) polymorphism [20], which was found to be present in approximately one-fifth of our population [69,70]. PNPLA3 is a functional enzyme with acyltransferase and/or lipase activity towards phospholipids and/or triglycerides and retinyl esters, respectively [71]. When mice, carrying a mutation at position 148 of the Pnpla3 gene were fed a high-sucrose diet, animals displayed increased levels of triglycerides and fatty acids, resulting in increased hepatic steatosis [72]. Nevertheless, no significant changes in hepatic inflammatory gene expression or fibrosis were observed [72]. Furthermore, in response to HFD, the development of hepatic steatosis was absent [72]. These data point towards diet as a primary trigger for PNPLA3-polymorphism-associated hepatic steatosis [72], thereby not covering the full spectrum of NAFLD.

Similarly, hepatic knockdown of transmembrane 6 superfamily member 2 (Tm6sf2), a gene responsible for regulating hepatic lipid metabolism and associated with increased susceptibility to human NAFLD [73], resulted in increased hepatic fat content and decreased VLDL secretion [74]. Though the specific role of Tm6sf2 gene is not yet known, these data point towards its contribution to NAFLD development, and hence, its translational applicability. Remarkably, a recent meta-analysis showed that rs58542926 polymorphism significantly associated with chronic liver disease in the overall population [73]. These novel data pointed towards the diagnostic ability of TM6SF2-polymorphism to identify individuals at higher risk for developing NAFLD, cirrhosis, and HCC, as well as alcohol-dependent liver disease [73].

Another recent study investigated the role of Gankyrin (Gank) [75], an oncogene frequently expressed in several types of cancer [76] and a strong driver of liver proliferation. Using mice carrying a liver-specific deletion in Gank, it was shown that feeding a HFD for 6-7 months prevented fibrosis development in Gank ${ }^{-1}$ mice compared to HFD-fed wild-type mice [75]. While Gank ${ }^{-1}$ mice showed a higher degree of hepatic steatosis compared to HFD-fed wild-type mice, it has been postulated that hepatic steatosis protects the liver from fibrosis, and therefore liver proliferation could be a trigger for hepatic fibrosis [75]. Hence, the therapeutic potential of inhibiting hepatic proliferation as a strategy against NAFLD should be further investigated.

A more recent genetically-modified model that has become popular in NAFLD research is the obese foz/foz mouse model, which carries an 11-base pair truncating mutation in the Alström gene Alms1 [12,14,77]. Alms1 is widely expressed and disrupted by mutations in a human obesity syndrome, referred to as Alstroöm syndrome [78]. When feeding a HFD within a time frame of ten months, foz/foz mice displayed features of MetS, including obesity, hyperglycemia, hyperlipidemia, and insulin 
resistance [77]. In addition, these mice spontaneously developed steatosis, hepatic inflammation, and fibrosis [77]. Yet, while all foz/foz models have shown to develop obesity, some develop higher NAFLD activity scores and/or fibrosis than others, implying that the severity of NASH in these mice is inconsistent [14]. Moreover, given that the exact role of Alms1 is not yet completely understood, the translational character of this model is rather limited.

Another mouse model that spontaneously develops hepatic inflammation with rather a mild degree of fibrosis is the lean polygenetic fatty liver Shionogi (FLS) [79,80]. Remarkably, when backcrossing these mice with $o b / o b$ mice, severe liver steatosis, inflammation, advanced fibrosis, and spontaneous HCC appeared to develop [81]. Nevertheless, due to its uncontrollable heterogeneity in disease onset, these models are scarcely used [82].

Other studies have used the hepatocyte-specific phosphatase and tensin homolog (PTEN)-deficient mouse model as a model for NAFLD [83,84]. PTEN, which is a phosphatase with activities towards both protein and lipids, was first discovered as a tumor suppressor protein [85]. More recently, its function as a metabolic regulator, also in the liver, has received increasing attention [85]. Indeed, PTEN-deficient mice were shown to display human-like lipid accumulation followed by liver fibrosis and HCC $[83,84]$. Nevertheless, these mice do not exhibit obvious human-like NASH features, such as increased circulating fatty acid levels and obesity, thereby limiting its translational potential.

In contrast, others studied the role of augmenter of liver regeneration $(A l r)$ in the context of NAFLD [86]. ALR, encoded by Growth Factor ERV1 homolog of Saccharomyces cerevisiae (Gfer), is an ubiquitous and multifunctional protein [86] that plays a vital role in liver generation, via regulating Natural Killer cell function [87], as well as other liver-related functions [88], including Kupffer cell activation [89]. Though mice deficient for Alr were prone to develop excessive hepatic steatosis [86], hepatic lipid accumulation was reversed at $4-8$ weeks. Despite reversal of steatosis, mice developed hepatic inflammation, including hepatocellular necrosis, ductal proliferation, and fibrosis, which preceded dysplasia and HCC tumor development by nearly $60 \%$ one year after birth $[11,86]$. Hence, this model could aid in better understanding the progression from hepatic necrosis, inflammation, and fibrosis to carcinogenesis.

Another example is the melanocortin 4 receptor knockout (Mc4r-/-) mouse model [90]. MC4R is a $G$ protein-coupled receptor expressed in hypothalamic nuclei being involved in regulating food intake and body weight [90]. Whereas chow-fed Mc4r-/- mice were shown to develop late onset obesity, hyperphagia, and simple steatosis due to genetic mutation, feeding a HFD induced ballooning degeneration, hepatic inflammation, and pericellular fibrosis [9]. In line with these results, using MRI-based techniques, Yamada et al. [91] recently showed that Mc4r-/- mice fed a HFD for 20 weeks developed obesity and NASH with clear signs of moderate fibrosis. Given their ability to functionally mimic the human NASH disease state, this model holds potential for studying hepatic dysfunction during advanced stages of NASH.

Alternative genetic models to study NASH progression and (spontaneously developing) HCC are the Tsumura-Suzuki Obese Diabetes (TSOD) mice, keratin 18-, NF- $\mathrm{kB}$ essential modulator (NEMO)-, and methionine adenosyltransferase 1A (MAT1a)-deficient models [92]. TSOD mice spontaneously developed NAFLD-related features, including T2D, obesity, glucosuria, hyperglycemia, and hyperinsulinemia without any special treatment [93]. Keratin 18 deficiency in mice serves as a model of NASH-associated liver carcinogenesis [94]. Liver-specific deletion of NEMO triggered steatosis, NASH, inflammatory fibrosis and subsequently HCC [95]. Mat1a gene deletion in mice impaired VLDL synthesis and plasma lipid homeostasis, thereby contributing to NAFLD development [96]. Yet, these models are generally less common and therefore less well-described in literature.

\subsection{Chemically-induced Murine Models}

As earlier described, alternative ways to explore the progression and/or regression of liver fibrosis and subsequent development of cirrhosis is by targeting the liver with $\mathrm{CCL}_{4}$ [57] or other chemotoxins, such as thioacetamide (TAA) $[8,11,12]$. For instance, biweekly administration of $\mathrm{CCl}_{4}$ for six weeks 
led to increased circulating aminotransferase and alkaline phosphatase levels in Balb/C mice [97]. In addition, $\mathrm{CCL}_{4}$ caused a dose-dependent progression of liver fibrosis [97]. However, the exact pathophysiological mechanism underlying hepatic fibrogenesis, in particular the role of hepatic stellate cells, requires further investigation.

More recently, co-administration of TAA and western-type diet for eight weeks in wild-type C57BL/6 mice was shown to induce hepatic inflammation, severe diffuse fibrosis, and collagen deposition [98]. Nevertheless, due to significant reductions in body weight, these models do not optimally resemble humanized NASH etiology.

One prominent model developed to better understand the progression from NAFLD to HCC is the STAM model, in which neonates received a low dose of streptozotocin, followed by a HFD starting from four weeks of age [99]. At 6 weeks, 8-12 weeks, and 16-20 weeks of age, these mice developed inflammation and hepatocellular ballooning, progressive fibrosis, and HCC, respectively [99]. Concomitantly, these mice had reduced body weight and insulin levels compared to HFD-fed mice [99]. These data imply that NAFLD progression is likely an artificial process that does not accurately reflect human disease pathology, thereby limiting its preclinical potential.

Similar to the clinical situation, many preclinical NAFLD studies in dietary and genetic models demonstrated increased severity in males [100,101]. However, it should be noted that sex differences may vary between models and genotypes [25,102]. For instance, we previously showed that female $\mathrm{Ldlr}^{-/}$and APOE2ki mice fed HFD displayed a very early hepatic inflammatory response [25]. Similarly, it was demonstrated that female C57BL/6 wild-type mice fed a high-fructose diet developed greater hepatic inflammation despite having similar liver steatosis as compared to male mice [103]. Other studies showed that female juvenile NAFLD/NASH models displayed hepatic oxidative stress, whereas male animals rather developed hepatic inflammation [104]. In line with these results, it was more recently shown that high fat intake $(60 \% \mathrm{kcal}$ and $34.9 \% \mathrm{~g}$ fat, $20 \% \mathrm{kcal}$ and $26.2 \% \mathrm{~g}$ protein, and $20 \% \mathrm{kcal}$ and $26.3 \% \mathrm{~g}$ carbohydrate) by juvenile female mice contributed to NAFLD development, whereas similar fat intake by maternal-offspring (i.e., high-fat intake two weeks before conception and during gestation and lactation) resulted in the successful establishment of NASH [105]. These data suggest that maternal exposure, as well as the HFD component, contribute to the degree of NAFLD disease severity in juvenile female offspring [105].

\subsection{Other Murine Models}

Besides a role for genetic and dietary factors in preclinical NAFLD development, recent focus has also discretely shifted towards the relevance of housing conditions, thereby introducing a novel concept of thermoneutral housing $\left(30-32^{\circ} \mathrm{C}\right)$ [106]. Compared to standard housing conditions, mice housed under thermoneutral conditions were not only shown to induce a pro-inflammatory immune response, but also to deteriorate HFD-induced NASH progression [106]. Additionally, mice displayed increased intestinal permeability and alterations in gut microbiome, features mimicking the human situation [106]. Although these hallmarks could also partially refute the sex bias that is often observed in murine models of NAFLD, there were no signs of hepatic fibrosis, neither in male nor in female C57BL/6 wild-type mice [106]. Altogether, these data propose that a dietary stimulus is prerequisite for liver fibrosis development.

It is well-known that the liver is a central metabolic organ, whose functions are capable of adapting to rhythmical changes of environment. Indeed, it has been previously shown that circadian rhythm is driving oscillations in hepatic triglyceride levels, inflammation, oxidative stress, mitochondrial dysfunction, and hepatic insulin resistance [107,108]. Moreover, it has been recently suggested that chronic disruption of circadian rhythm may spontaneously induce the progression from NAFLD to NASH, fibrosis, and HCC $[20,109]$, similar to the human situation, pointing towards its translational value.

Last but not least, there has also been increased awareness on the validity and reproducibility of preclinical studies on NAFLD [110-112]. For instance, it has been shown that murine liver fibrosis 
is affected by sampling variation [8]. More recently, Jensen et al. [2] demonstrated that feeding wild-type C57BL/6 mice a high-fat/high-fructose/high-cholesterol diet (40\%/20\%/2\%) for 16 weeks resulted in significant intraindividual differences in fibrosis score and several hepatic biomarkers. Nevertheless, differences in sample variation were absent in other routinely used NAFLD rodent models [2]. These data pointed towards the importance of standardizing sampling site location during preclinical liver biopsy procedures, thereby supporting the ability to compare experimental outcomes between individual murine NASH studies.

\subsection{Rat NAFLD Models}

In addition to the importance of murine models, preclinical studies on NAFLD pathogenesis are also frequently performed using rats. Rat models are thought to be more susceptible to HFD, and thus may display more severe and/or earlier histological features of NAFLD compared to mice [113]. A small selection of rat studies on NAFLD will be highlighted in this section.

Similar to mice, commonly used rat models refer to nutritional, genetic, and combined models (extensively reviewed elsewhere [114,115]), of which Sprague-Dawley [116,117], Wistar [118], and/or diabetic Zucker rats (fa/fa) [119] are well-known examples. For instance, Lieber et al. [120] and others [117] reported that Sprague-Dawley rats on a HFD (71\% fat $/ 11 \%$ carbohydrates/18\% proteins) were able to develop insulin resistance, mild-to-marked steatosis, inflammation and/or fibrogenesis, thereby reproducing key features of human NASH. Yet, when fed a standard Lieber-DeCarli diet ( $35 \%$ fat, $47 \%$ carbohydrates, $18 \%$ proteins), rats displayed no signs of steatosis, inflammation, or fibrosis [120]. Diabetic Zucker rats, a well-characterized model of NAFLD, displayed similar features as its murine counterparts $o b / o b$ and $d b / d b$ mice, i.e., spontaneous development of severe obesity, steatosis, and insulin resistance [11]. Moreover, it was shown that Zucker rats are in need of an additional stimulus for onset of NASH [119]. Relevantly, when comparing 4 weeks of MCD diet between different rat models (i.e., Wistar, Long-Evans, and Sprague-Dawley rats), the Wistar strain was associated with the highest degree of hepatic fat accumulation [121], pointing either towards strain-dependency or the impact of dietary exposure time.

Altogether, rat models are useful tools for providing additional valuable insights into the complex pathogenesis of steatosis/NASH (but not HCC), even though dietary or chemical interventions in these animals do not fully resemble the human situation.

\section{Therapeutic Approaches in Preclinical NAFLD Models}

In addition to exploring NAFLD etiology, preclinical models are critically important for testing how potential therapeutic drugs can interfere with the progression of this chronic disease [115].

Previously, Zheng et al. [27] chronically exposed HFC-treated mice with Ezetimibe, which is known to reduce plasma LDL by selectively binding to the intestinal cholesterol transporter Niemann-Pick type C1-like 1. After four weeks of Ezetimibe, significant improvements in fatty liver were observed, which were associated with a decrease in hepatic triglycerides, cholesteryl esters, and free cholesterol [27]. Additionally, chronic treatment with Ezetimibe resulted in significant reductions in plasma ALT activity, pointing towards its ability to serve as a novel treatment for HFC-induced NAFLD [27].

Trevaskis et al. [51] treated HFD-induced wild-type C57BL/6 and ob/ob mice with GLP-1R agonist AC3174, an exenatide analog. AC3174 treatment significantly reduced intrahepatic lipid accumulation, plasma triglycerides, and ALT levels, likely due to its contribution in weight loss [51]. Additionally, data suggested that AC3174 modestly improved the histological severity of fibrosis, which was demonstrated by a decrease in liver collagen-1 protein. Altogether, these findings suggest that AC3174 may play a beneficial role in the treatment of key aspects of fibrotic NASH.

Domitrovic et al. [97] investigated the therapeutic effect of luteolin in the context of liver fibrosis. Luteolin is a member of the flavonoid family, which has shown to exhibit hepatoprotective activity in acute liver damage, amongst others [122]. Administration of luteolin to $\mathrm{CCL}_{4}$-treated mice resulted in a dose-dependent reduction in hepatic fibrosis [97]. Although studies on the impact of luteolin in a 
more chronic model of liver fibrosis are desired, these data pointed towards therapeutic application of this drug in patients with hepatic fibrosis [97]. Similarly, in a study of Ganbold et al. [3], it was recently shown that administration of isorhamnetin, another natural flavonoid to human-like NASH mice, resulted in improved steatosis, liver injury, and fibrosis, pointing towards its therapeutic potential in NASH.

More recently, Khurana et al. [117] studied the role of inhibiting extracellular cathepsin D, a lysosomal enzyme that plays a role in lipid-related disorders, including NAFLD [123,124]. Using HFD-fed Sprague-Dawley rats, it was shown that inhibition of extracellular cathepsin D improved hepatic steatosis and reduced plasma levels of insulin and hepatic transaminases [117]. These data suggest that modulation of extracellular cathepsins may serve as a novel therapeutic modality for NAFLD [117].

Gehrke et al. [125] recently investigated eight to ten week-old wild-type C57BL/6 male mice that were fed an obesogenic diet (fructose/glucose supplementation in drinking water). In this study, mice were either challenged with voluntary wheel running or were kept on a sedentary lifestyle intervention [125]. Similar to well-known forced exercise models [126], voluntary wheel running protected these mice from HFD-induced pro-inflammatory and pro-fibrogenic states, as shown by decreased hepatic macrophage infiltration and improved fatty acid and glucose homeostasis. These data were in line with Kawanishi et al. [126], showing that exercise training reduced macrophage infiltration and adipose tissue inflammation by attenuating neutrophil infiltration in HFD-fed C57BL/6 mice. Thus, it is very likely that physical exercise exhibits beneficial effects and compensates for shortcomings of certain therapeutic approaches $[125,126]$.

Table 1. Overview of commonly used dietary, genetic, chemically-induced, and other murine models of non-alcoholic steatohepatitis (NASH).

\begin{tabular}{|c|c|c|c|}
\hline Type of Mouse Model & $\begin{array}{l}\text { Treatment or } \\
\text { Intervention }\end{array}$ & $\begin{array}{l}\text { Phenotypical Outcome and Relevance to } \\
\text { Human Disease }\end{array}$ & Author(s) \\
\hline \multicolumn{4}{|c|}{ Dietary Models } \\
\hline Atherogenic diet & $\begin{array}{l}\text { Diet containing } 1.25 \% \\
\text { cholesterol and } 0.5 \% \\
\text { cholate }\end{array}$ & $\begin{array}{l}\text { Increased plasma and liver lipid levels. } \\
\text { From 6-24 weeks, induction NASH with } \\
\text { hepatocellular ballooning in a } \\
\text { time-dependent manner. }\end{array}$ & Matsuzawa et al. [24] \\
\hline High-fat atherogenic diet & $\begin{array}{l}\text { HFD containing } 1.25 \% \\
\text { cholesterol and } 0.5 \% \\
\text { cholate }\end{array}$ & $\begin{array}{l}\text { Exacerbated NASH features including } \\
\text { hepatic insulin resistance, oxidative stress, } \\
\text { activation of hepatic stellate cells. }\end{array}$ & $\begin{array}{l}\text { Matsuzawa et al. [24], } \\
\text { Montandon et al. [41], } \\
\text { Larter et al. [42] }\end{array}$ \\
\hline $\begin{array}{l}\text { High-fat/high-cholesterol diet } \\
\text { (HFC) }\end{array}$ & $\begin{array}{l}\text { HFC containing } 21 \% \\
\text { milk butter, } 0.2 \% \\
\text { cholesterol }\end{array}$ & $\begin{array}{l}\text { After short-term HFC diet, only steatosis in } \\
\text { C57BL/6 mice. } \\
\text { Steatosis with severe inflammation in } \\
\text { female } L d l r^{--} \text {and APOE2ki hyperlipidemic } \\
\text { mice. } \\
\text { After seven days, severe hepatic } \\
\text { inflammation but no steatosis in male } \\
\text { hyperlipidemic mice. } \\
\text { After seven months, development of } \\
\text { obesity, hepatomegaly, hepatic steatosis and } \\
\text { varying degrees of steatohepatitis in } \\
\text { C57BL/6 mice. }\end{array}$ & $\begin{array}{l}\text { Wouters et al. [25,26] } \\
\text { Zheng et al. [27] }\end{array}$ \\
\hline $\begin{array}{l}\text { High-fat/high-cholesterol/ } \\
\text { high-fructose diet } \\
\text { (AMLN) }\end{array}$ & $\begin{array}{l}\text { Diet containing } 40 \% \\
\text { high-fat and } 22 \% \\
\text { fructose, supplemented } \\
\text { with } \sim 18 \% \text { trans-fat and } \\
2 \% \text { cholesterol }\end{array}$ & $\begin{array}{l}\text { After } 26-30 \mathrm{w}, \text { marked steatosis, moderate } \\
\text { lobular inflammation and hepatocellular } \\
\text { ballooning in C57BL/ } 6 \text { and } o b / o b \text { mice. }\end{array}$ & $\begin{array}{l}\text { Clapper et al. [28], } \\
\text { Kristiansen et al. [29] }\end{array}$ \\
\hline
\end{tabular}


Table 1. Cont

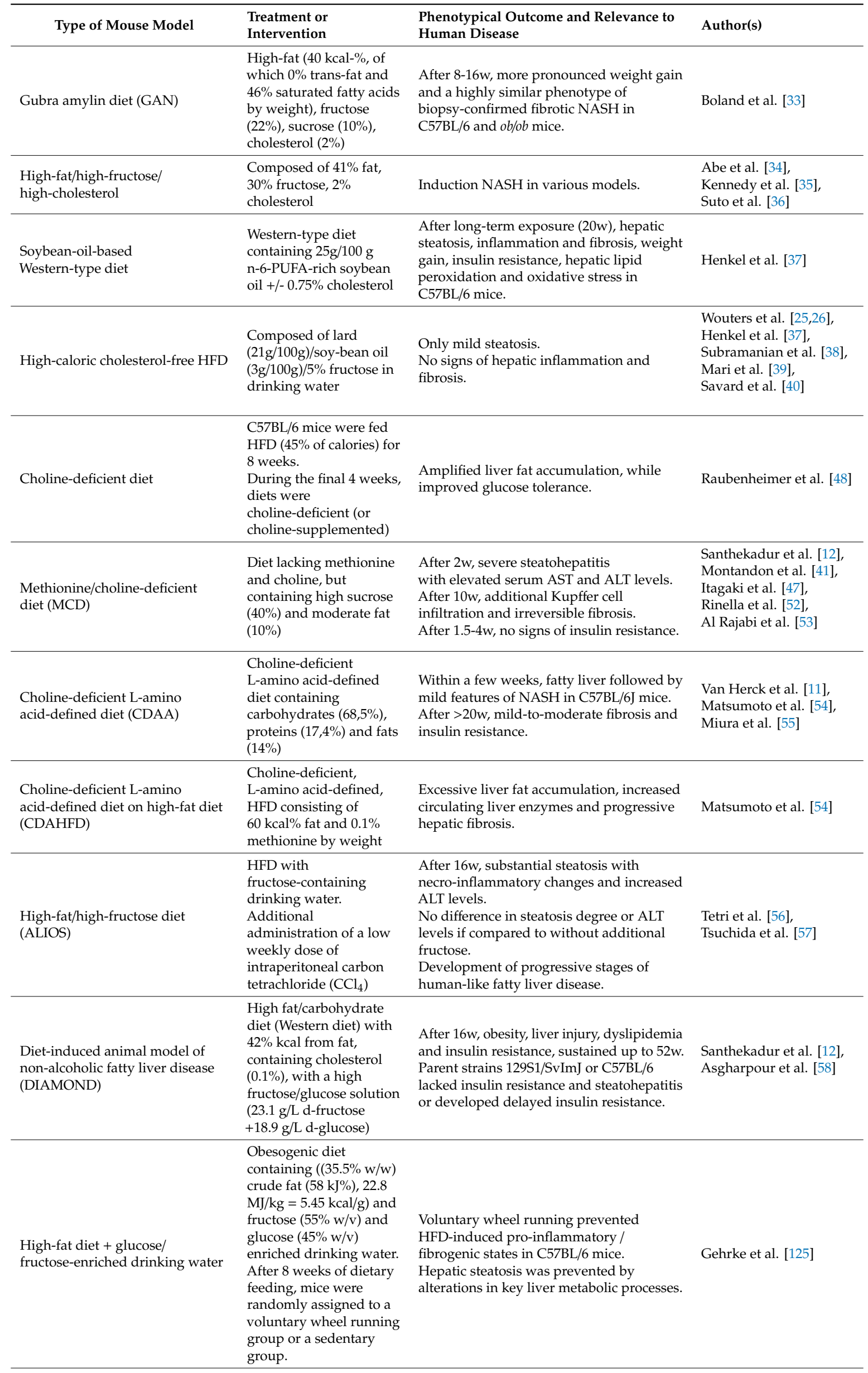


Table 1. Cont.

\begin{tabular}{|c|c|c|c|}
\hline Type of Mouse Model & $\begin{array}{l}\text { Treatment or } \\
\text { Intervention }\end{array}$ & $\begin{array}{l}\text { Phenotypical Outcome and Relevance to } \\
\text { Human Disease }\end{array}$ & Author(s) \\
\hline \multicolumn{4}{|c|}{ Genetic Models } \\
\hline Leptin resistance $(d b / d b)$ & $\begin{array}{l}d b / d b \text { mice are deficient in } \\
\text { the leptin receptor, with } \\
\text { dramatic elevations in } \\
\text { circulating leptin } \\
\text { concentrations. } \\
\text { Dietary intervention } \\
\text { with an MCD diet for } 4 \\
\text { weeks. }\end{array}$ & $\begin{array}{l}\text { Lack the ability to spontaneously develop } \\
\text { hepatic inflammation and thus needs to be } \\
\text { combined with a nutritional model for } \\
\text { NASH. } \\
\text { After } 4 \mathrm{w} \text { MCD diet, mice displayed marked } \\
\text { hepatic inflammation and fibrosis. }\end{array}$ & $\begin{array}{l}\text { Kennedy et al. [35], } \\
\text { Sahai et al. [45], } \\
\text { Hummel et al. [50] }\end{array}$ \\
\hline MS-NASH (FATZO/Pco) & $\begin{array}{l}\text { Mice spontaneous } \\
\text { development of obesity }\end{array}$ & $\begin{array}{l}\text { After 20w of fructose-supplemented diet, } \\
\text { hepatic steatosis, lobular inflammation, } \\
\text { ballooning and fibrosis. }\end{array}$ & Sun et al. [62] \\
\hline $\begin{array}{l}\text { Apolipoprotein E2 knock-in } \\
\text { (APOE2) }\end{array}$ & $\begin{array}{l}\text { Murine ApoE replaced } \\
\text { by the human APOE2 } \\
\text { gene }\end{array}$ & $\begin{array}{l}\text { After } 12 \mathrm{w} \text { of HFC, steatosis in conjunction } \\
\text { with early but not sustained hepatic } \\
\text { inflammation. }\end{array}$ & $\begin{array}{l}\text { Wouters et al. [25,26], } \\
\text { Bieghs et al. [63] }\end{array}$ \\
\hline ApoE deficiency $\left(A p o E^{-/-}\right)$ & $\begin{array}{l}\text { Complete deficiency in } \\
\text { the murine ApoE gene }\end{array}$ & $\begin{array}{l}\text { After } 7 w \text { of Western diet, abnormal glucose } \\
\text { tolerance, hepatomegaly, weight gain and } \\
\text { full spectrum of NASH, while lacking } \\
\text { humanized lipoprotein profiles. }\end{array}$ & Schierwagen et al. [64] \\
\hline $\begin{array}{l}\text { Microsomal prostaglandin E } \\
\text { synthase } 1 \text { (mPGES1) } \\
\text { deficiency }\end{array}$ & $\begin{array}{l}\text { Mice with global deletion } \\
\text { of mPGES-133 were } \\
\text { backcrossed on C57BL/6J }\end{array}$ & $\begin{array}{l}\text { TNF } \alpha \text {-dependent inflammatory response in } \\
\text { murine liver. } \\
\text { Increased severity of diet-induced murine } \\
\text { NASH. }\end{array}$ & Henkel et al. [65] \\
\hline $\begin{array}{l}\text { Patatin-like phospholipase } \\
\text { domain-containing } 3 \text { (PNPLA-3) } \\
\text { knock-in }\end{array}$ & $\begin{array}{l}\text { Mice carried I148M } \\
\text { mutation in the Pnpla3 } \\
\text { gene and were fed a } \\
\text { high-sucrose or HFD diet } \\
\text { for } 4 \text { weeks }\end{array}$ & $\begin{array}{l}\text { Accumulation of PNPLA3 on lipid droplets. } \\
\text { Development of hepatic steatosis. }\end{array}$ & Smagris et al. [72] \\
\hline $\begin{array}{l}\text { Transmembrane } 6 \text { superfamily } \\
\text { member } 2 \text { knockdown } \\
\text { (mTm6s2-shRNA8) }\end{array}$ & $\begin{array}{l}\text { Adeno-associated } \\
\text { virus-mediated short } \\
\text { hairpin RNA } \\
\text { knockdown of Tm6sf2 in } \\
\text { liver of C57BL/6J mice }\end{array}$ & $\begin{array}{l}\text { Increased hepatic fat content and decreased } \\
\text { VLDL secretion, recapitulating the effects } \\
\text { observed in humans carrying the } \\
\text { TM6SF2-167Lys mutation }\end{array}$ & Kozlitina et al. [74] \\
\hline $\begin{array}{l}\text { Gankyrin liver-specific knockout } \\
(\text { GLKO) }\end{array}$ & $\begin{array}{l}\text { Cre-Alb mice were } \\
\text { backcrossed with } \\
\text { LoxP-Gank mice }\end{array}$ & $\begin{array}{l}\text { Gankyrin generally drives liver } \\
\text { proliferation. } \\
\text { After 6-7 months of HFD, higher degree of } \\
\text { hepatic steatosis but prevention of fibrosis } \\
\text { development in GLKO mice compared to } \\
\text { wild-type mice. }\end{array}$ & Cast et al. [75] \\
\hline
\end{tabular}


Table 1. Cont.

\begin{tabular}{|c|c|c|c|}
\hline Type of Mouse Model & $\begin{array}{l}\text { Treatment or } \\
\text { Intervention }\end{array}$ & $\begin{array}{l}\text { Phenotypical Outcome and Relevance to } \\
\text { Human Disease }\end{array}$ & Author(s) \\
\hline Fatty liver Shionogi & $\begin{array}{l}\text { Spontaneous } \\
\text { development of hepatic } \\
\text { inflammation with rather } \\
\text { a mild degree of fibrosis. } \\
\text { Uncontrollable } \\
\text { heterogeneity in disease } \\
\text { onset }\end{array}$ & $\begin{array}{l}\text { Backcrossing with } o b / o b \text { mice resulted in } \\
\text { severe liver steatosis, inflammation, } \\
\text { advanced fibrosis and spontaneous HCC }\end{array}$ & He et al. [82] \\
\hline $\begin{array}{l}\text { Hepatocyte-specific phosphatase } \\
\text { and tensin homolog deficiency } \\
\left(\text { Pten }^{-/}\right)\end{array}$ & $\begin{array}{l}\text { PTEN deficiency specific } \\
\text { in the liver }\end{array}$ & $\begin{array}{l}\text { After } 40 \mathrm{w} \text { of age, steatosis, inflammation } \\
\text { and fibrosis in the liver. } \\
\text { After } 74-78 \mathrm{w} \text { of age, HCC was present in } \\
83 \% \text { of males and } 50 \% \text { of female mice. }\end{array}$ & $\begin{array}{l}\text { Watanabe et al. [83], } \\
\text { Takakura et al. [84] }\end{array}$ \\
\hline $\begin{array}{l}\text { Augmenter of liver regeneration } \\
\text { knock-out }\left(A l r^{-/-}\right)\end{array}$ & $\begin{array}{l}\text { Liver-specific deletion of } \\
\text { augmenter of liver } \\
\text { regeneration }\end{array}$ & $\begin{array}{l}\text { 4-8w after birth, steatohepatitis with } \\
\text { hepatocellular necrosis, ductular } \\
\text { proliferation and fibrosis. } \\
\text { 1y after birth, HCC in nearly } 60 \% \text { of the } \\
\text { mice }\end{array}$ & $\begin{array}{l}\text { Van Herck et al. [11], } \\
\text { Gandhi et al. [89] }\end{array}$ \\
\hline $\begin{array}{l}\text { Melanocortin } 4 \text { receptor knockout } \\
\left(M c 4 r^{--}\right)\end{array}$ & $\begin{array}{l}\text { Mice with targeted } \\
\text { disruption of } \\
\text { melanocortin } 4 \text { receptor, } \\
\text { which is a } \\
\text { seven-transmembrane G } \\
\text { protein-coupled receptor } \\
\text { that is expressed in the } \\
\text { hypothalamic nuclei }\end{array}$ & $\begin{array}{l}\text { Development of simple steatosis. } \\
\text { Upon feeding HFD, development of } \\
\text { human-like NASH, including obesity, } \\
\text { insulin resistance and dyslipidemia. } \\
\text { After 20w HFD, obesity and NASH with } \\
\text { clear signs of moderate fibrosis, functionally } \\
\text { mimicking the human NASH disease state. }\end{array}$ & $\begin{array}{l}\text { Itoh et al. [90], } \\
\text { Yamada et al. [91] }\end{array}$ \\
\hline \multicolumn{4}{|c|}{ Chemically-induced Models } \\
\hline Carbon tetrachloride $\left(\mathrm{CCL}_{4}\right)$ & $\begin{array}{l}\text { Biweekly injections of } \\
\mathrm{CCl}_{4}\end{array}$ & $\begin{array}{l}\text { After } 6 \mathrm{w} \text {, increased circulating liver } \\
\text { enzymes and dose-dependent progression } \\
\text { of liver fibrosis in Balb/C mice }\end{array}$ & Domitrovic et al. [97] \\
\hline $\begin{array}{l}\text { Streptozotocin + high-fat diet } \\
\text { (STAM) }\end{array}$ & $\begin{array}{l}200 \mu \mathrm{g} \text { streptozotocin at } \\
2 \text { days after birth and } \\
\text { feeding ad libitum with } \\
\text { high-fat diet at } 4 \text { weeks } \\
\text { of age }\end{array}$ & $\begin{array}{l}\text { Between 6-20w of age, hepatic } \\
\text { inflammation, hepatocellular ballooning, } \\
\text { progressive fibrosis and HCC. } \\
\text { Reduced body weight and insulin levels } \\
\text { compared to HFD-fed mice }\end{array}$ & Fujii et al. [99] \\
\hline \multicolumn{4}{|c|}{ Other models } \\
\hline C57BL/6 background & $\begin{array}{l}\text { Mice were housed in } \\
\text { separate specific } \\
\text { pathogen-free units } \\
\text { maintained at either } \\
22^{\circ} \mathrm{C} \text { (standard) or } \\
30-33^{\circ} \mathrm{C} \text { (thermoneutral) }\end{array}$ & $\begin{array}{l}\text { After } 24 w \text { of thermoneutral housing, } \\
\text { exacerbated HFD-driven NAFLD } \\
\text { pathogenesis. } \\
\text { Increased intestinal permeability and } \\
\text { alterations in gut microbiome, mimicking } \\
\text { the human situation. }\end{array}$ & Giles et al. [106] \\
\hline C57BL/6 background & $\begin{array}{l}\text { Juvenile NASH model: } \\
\text { immediately after } \\
\text { weaning, mice were fed } \\
\text { HFC diet for a total of } 16 \\
\text { weeks }(4,8,12 \text { and } 16 \\
\text { weeks of diet) }\end{array}$ & $\begin{array}{l}\text { Hepatic oxidative stress in female juvenile } \\
\text { NAFLD/NASH models, whereas hepatic } \\
\text { inflammation in males }\end{array}$ & Marin et al. [104] \\
\hline C57BL/6 background & $\begin{array}{l}\text { Juvenile NAFLD/NASH } \\
\text { model: HFD were } \\
\text { administered } 2 \text { weeks } \\
\text { before conception and } \\
\text { during gestation and } \\
\text { lactation }\end{array}$ & $\begin{array}{l}\text { Offspring HFC intake resulted in NAFLD, } \\
\text { maternal-offspring fat intake contributed to } \\
\text { NASH in juvenile female mice }\end{array}$ & Zhou et al. [105] \\
\hline $\begin{array}{l}\text { Models with circadian oscillations } \\
\text { (e.g., Per } 1 / 2^{-/-} \text {or liver-specific } \\
\text { Bmal1 knockout mice) }\end{array}$ & $\begin{array}{l}\text { The effects of feeding } \\
\text { time and circadian clocks } \\
\text { on murine liver }\end{array}$ & $\begin{array}{l}\text { Circadian rhythm drives oscillations in } \\
\text { hepatic triglyceride levels, inflammation, } \\
\text { oxidative stress, mitochondrial dysfunction } \\
\text { and hepatic insulin resistance. } \\
\text { Chronic disruption of circadian rhythm } \\
\text { may spontaneously induce the progression } \\
\text { from NAFLD to NASH, fibrosis and HCC }\end{array}$ & $\begin{array}{l}\text { Adamovich et al. [107], } \\
\text { Jacobi et al. [108], } \\
\text { Kettner et al. [109] }\end{array}$ \\
\hline C57BL/6 background & $\begin{array}{l}\text { Mice (and other rodent } \\
\text { models) were fed a } \\
\text { high-fat/high-fructose/ } \\
\text { high-cholesterol for } 16 \\
\text { weeks }\end{array}$ & $\begin{array}{l}\text { Significant intraindividual differences in } \\
\text { fibrosis score and hepatic biomarkers } \\
\text { pointed towards the importance of } \\
\text { standardizing sampling site location during } \\
\text { preclinical liver biopsy procedures }\end{array}$ & Jensen et al. [2] \\
\hline
\end{tabular}




\section{Clinical Relevance: Comparisons with Clinical Data}

In general, NAFLD is considered the hepatic manifestation of MetS. Consequently, well-established therapeutic compounds against T2D and impaired lipid metabolism are thought to exert beneficial effects that mitigate the pathological features of NASH. One such example is the nuclear receptor peroxisome proliferator-activated receptor (PPAR) (extensively reviewed elsewhere [127]), due to its involvement in regulating lipid metabolism and inflammation. For instance, it was previously shown that hepatic Ppara inversely correlated with insulin resistance and NASH severity [128]. Remarkably, in this clinical study, histological improvements were positively associated with Ppar $\alpha$ expression in patients with NASH [128], pointing towards the therapeutic potential of PPAR $\alpha$-agonists. Fibrates, which activate PPAR $\alpha$, are the most effective class of agents for lowering elevated triglyceride-rich lipoproteins [129]. While fenofibrate did not ameliorate liver histology in biopsy-proven NAFLD, a selective PPAR $\alpha$ agonist, also known as Pemafibrate, did improve liver function in patients with dyslipidemia [130], which was previously established in diet-induced murine models of NAFLD [131].

Another isoform of PPAR, PPAR- $\delta$, is involved in dyslipidemia and activation of PPAR- $\delta$ by means of a selective agonist, referred to as seladelpar (MBX-8025), beneficially affected plasma lipid levels and showed favorable trends in insulin resistance and waist circumference in patients with dyslipidemia [132]. More recently, these data were further supported using in-vivo studies, showing that seladelpar improved glucose metabolism, as well as plasma and hepatic lipid levels in obese foz/foz mice [133]. Collectively, these data pointed towards seladelpar as a potential novel therapy for NASH.

Another strategy is based on insulin-sensing drugs, known as Thiazolidinediones, which target the PPAR- $\gamma$ isoform [134]. Examples of PPAR- $\gamma$ agonists are lobeglitazone, pioglitazone, and rosiglitazone, of which the latter two are currently off-label and off-market, respectively [127]. When diabetic patients with NAFLD were treated with lobeglitazone, patients showed improvements in hepatic steatosis, glycemic, and lipid profiles, as well as liver enzyme levels [134]. In line, it was shown that HFD-induced obese mice treated with lobeglitazone improved glucose homeostasis as well as hepatic and plasma lipid levels [135]. Hence, these data pointed towards lobeglitazone as a potential treatment option for NAFLD.

Relevantly, the use of elafibranor (dual PPAR- $\alpha / \delta$ agonist, clinical phase III trial) as a single drug regime is thought to be promising with regard to NASH, as shown by significant improvements of human NASH pathology without deteriorating hepatic fibrosis [136]. These data were further corroborated by findings in rodent studies of NAFLD [137]. Additionally, the development of anti-fibrotic therapies has recently received increasing attention [138]. Therefore, due to its multifactorial character, current treatment modalities should focus on both the reversal of NASH [139] and fibrosis [138].

Strategies, which currently hold clinical potential in late-stage drug development, include specific complementary agonists, i.e., for PPAR receptor subtypes and farnesoid X receptor (FXR) [139]. Using AMLN diet-induced obese mice with biopsy-confirmed NASH, Roth et al. [139] demonstrated that combined treatment with Elafibrinor and obeticholic acid (FXR agonist) significantly ameliorated histological features of steatosis, inflammation and fibrosis. Additionally, compared to single regimens, combined treatment targeted hepatic molecular mechanisms, thereby further improving NASH and fibrogenesis [139].

To conclude, in addition to the selective- but relevant-approaches described above, additional therapeutic options for NAFLD have been studied in preclinical and/or clinical settings [16], or are currently under investigation.

\section{Conclusions}

Although current preclinical NAFLD models can be considered indispensable tools for studying chronic liver disease pathology, it should be noted that the majority of existing rodent models mainly focus on certain stages of the disease rather than the total spectrum. Additionally, it is noteworthy that the NAFLD disease progression greatly varies across different strains [140]. Therefore, depending on its 
research question, careful model selection is highly recommended. Such selection should also properly consider sex, age, and hormonal status and must be based on prior knowledge, as it will have a large impact on data interpretation and its translational potential. Thus, our common goal is to establish an ideal preclinical model that-in addition to developing hepatic inflammation and fibrosis, along with obesity, high cholesterol, and insulin resistance-also responds to promising therapeutic interventions. This implies that future studies should continue focusing on recapitulating the multifactorial character of human NAFLD in preclinical models.

Author Contributions: Conceptualization, writing—original draft preparation and writing—review and editing, figure preparation, Y.O. and R.S.-S.; funding acquisition, R.S.-S. All authors have read and agreed to the published version of the manuscript.

Funding: This research was funded by the Dutch Organization for Scientific Research (NWO; VIDI grant no. 016.126.327), ASPASIA (grant no. 015.008.043) and TKI-LSH (grant no. 40-41200-98-9306).

Conflicts of Interest: The authors declare no conflict of interest.

\section{Abbreviations}

$\begin{array}{ll}\text { ALIOS } & \text { American Lifestyle Induced Obesity Syndrome } \\ \text { ALMS1 } & \text { Alström } \\ \text { ALR } & \text { Augmenter of liver regeneration } \\ \text { APOE2ki } & \text { Apolipoprotein E2 knock-in } \\ \text { CCl } & \text { Carbon tetrachloride } \\ \text { CD } & \text { Diet deficient for/low in choline } \\ \text { CDAA } & \text { Choline-deficient L-amino acid-defined diet } \\ \text { DIAMOND } & \text { Diet-induced animal model of non-alcoholic fatty liver disease } \\ \text { FLS } & \text { Fatty liver Shionogi } \\ \text { FXR } & \text { Farnesoid X receptor } \\ \text { Gank } & \text { Gankyrin } \\ \text { GFER } & \text { Growth Factor ERV1 homolog of Saccharomyces cerevisiae } \\ \text { HCC } & \text { Hepatocellular carcinoma } \\ \text { HFC } & \text { High-fat/high-cholesterol diet } \\ \text { HFD } & \text { High-fat diet } \\ \text { Ldlr } & \text { Low-density lipoprotein receptor } \\ \text { MAT1a } & \text { methionine adenosyltransferase 1A } \\ \text { MC4R } & \text { Melanocortin } 4 \text { receptor } \\ \text { MetS } & \text { Metabolic Syndrome } \\ \text { MS-NASH } & \text { Mice formerly known as FATZO/Pco } \\ \text { NAFLD } & \text { Non-alcoholic fatty liver disease } \\ \text { NASH } & \text { Non-alcoholic steatohepatitis } \\ \text { NEMO } & \text { NF-kB essential modulator } \\ \text { PNPLA3 } & \text { Patatin-like phospholipase domain-containing 3 } \\ \text { PPAR } & \text { Peroxisome proliferator-activated receptor } \\ \text { PTEN } & \text { Phosphatase and tensin homolog } \\ \text { T2D } & \text { Type 2 Diabetes } \\ \text { TAA } & \text { Thioacetamide } \\ \text { TM6SF2 } & \text { Transmembrane 6 superfamily member 2 } \\ \text { TNF } \alpha & \text { Tsumura-Suzuki Obese Diabetes } \\ \text { TSOD } & \\ & \end{array}$

\section{References}

1. Younossi, Z.M.; Golabi, P.; de Avila, L.; Paik, J.M.; Srishord, M.; Fukui, N.; Qiu, Y.; Burns, L.; Afendy, A.; Nader, F. The global epidemiology of NAFLD and NASH in patients with type 2 diabetes: A systematic review and meta-analysis. J. Hepatol. 2019, 71, 793-801. [CrossRef] [PubMed] 
2. Jensen, V.S.; Tveden-Nyborg, P.; Zacho-Rasmussen, C.; Quaade, M.L.; Ipsen, D.H.; Hvid, H.; Fledelius, C.; Wulff, E.M.; Lykkesfeldt, J. Variation in diagnostic NAFLD/NASH read-outs in paired liver samples from rodent models. J. Pharmacol. Toxicol. Methods 2019, 101, 106651. [CrossRef] [PubMed]

3. Ganbold, M.; Owada, Y.; Ozawa, Y.; Shimamoto, Y.; Ferdousi, F.; Tominaga, K.; Zheng, Y.W.; Ohkohchi, N.; Isoda, H. Isorhamnetin Alleviates Steatosis and Fibrosis in Mice with Nonalcoholic Steatohepatitis. Sci. Rep. 2019, 9, 16210. [CrossRef] [PubMed]

4. Li, B.; Zhang, C.; Zhan, Y.T. Nonalcoholic Fatty Liver Disease Cirrhosis: A Review of Its Epidemiology, Risk Factors, Clinical Presentation, Diagnosis, Management, and Prognosis. Can. J. Gastroenterol. Hepatol. 2018, 2018, 2784537. [CrossRef] [PubMed]

5. Anstee, Q.M.; Reeves, H.L.; Kotsiliti, E.; Govaere, O.; Heikenwalder, M. From NASH to HCC: Current concepts and future challenges. Nat. Rev. Gastroenterol. Hepatol. 2019, 16, 411-428. [CrossRef] [PubMed]

6. Wong, R.J.; Cheung, R.; Ahmed, A. Nonalcoholic steatohepatitis is the most rapidly growing indication for liver transplantation in patients with hepatocellular carcinoma in the U.S. Hepatology 2014, 59, 2188-2195. [CrossRef]

7. Younossi, Z.M.; Loomba, R.; Anstee, Q.M.; Rinella, M.E.; Bugianesi, E.; Marchesini, G.; Neuschwander-Tetri, B.A.; Serfaty, L.; Negro, F.; Caldwell, S.H.; et al. Diagnostic modalities for nonalcoholic fatty liver disease, nonalcoholic steatohepatitis, and associated fibrosis. Hepatology 2018, 68, 349-360. [CrossRef]

8. Hansen, H.H.; Feigh, M.; Veidal, S.S.; Rigbolt, K.T.; Vrang, N.; Fosgerau, K. Mouse models of nonalcoholic steatohepatitis in preclinical drug development. Drug Discov. Today 2017. [CrossRef]

9. Haczeyni, F.; Yeh, M.M.; Ioannou, G.N.; Leclercq, I.A.; Goldin, R.; Dan, Y.Y.; Yu, J.; Teoh, N.C.; Farrell, G.C. Mouse models of non-alcoholic steatohepatitis: A reflection on recent literature. J. Gastroenterol. Hepatol. 2018, 33, 1312-1320. [CrossRef]

10. Lau, J.K.; Zhang, X.; Yu, J. Animal models of non-alcoholic fatty liver disease: Current perspectives and recent advances. J. Pathol. 2017, 241, 36-44. [CrossRef]

11. Van Herck, M.A.; Vonghia, L.; Francque, S.M. Animal Models of Nonalcoholic Fatty Liver Disease-A Starter's Guide. Nutrients 2017, 9, 1072. [CrossRef] [PubMed]

12. Santhekadur, P.K.; Kumar, D.P.; Sanyal, A.J. Preclinical models of non-alcoholic fatty liver disease. J. Hepatol. 2018, 68, 230-237. [CrossRef] [PubMed]

13. Jahn, D.; Kircher, S.; Hermanns, H.M.; Geier, A. Animal models of NAFLD from a hepatologist's point of view. Biochim. Biophys. Acta Mol. Basis Dis. 2019, 1865, 943-953. [CrossRef] [PubMed]

14. Jiang, M.; Wu, N.; Chen, X.; Wang, W.; Chu, Y.; Liu, H.; Li, W.; Chen, D.; Li, X.; Xu, B. Pathogenesis of and major animal models used for nonalcoholic fatty liver disease. J. Int. Med. Res. 2019, 47, 1453-1466. [CrossRef] [PubMed]

15. Palladini, G.; Di Pasqua, L.G.; Berardo, C.; Siciliano, V.; Richelmi, P.; Perlini, S.; Ferrigno, A.; Vairetti, M. Animal Models of Steatosis (NAFLD) and Steatohepatitis (NASH) Exhibit Hepatic Lobe-Specific Gelatinases Activity and Oxidative Stress. Can. J. Gastroenterol. Hepatol. 2019, 2019, 5413461. [CrossRef]

16. Zhong, F.; Zhou, X.; Xu, J.; Gao, L. Rodent Models of Nonalcoholic Fatty Liver Disease. Digestion 2019, 1-14. [CrossRef]

17. Velazquez, K.T.; Enos, R.T.; Bader, J.E.; Sougiannis, A.T.; Carson, M.S.; Chatzistamou, I.; Carson, J.A.; Nagarkatti, P.S.; Nagarkatti, M.; Murphy, E.A. Prolonged high-fat-diet feeding promotes non-alcoholic fatty liver disease and alters gut microbiota in mice. World J. Hepatol. 2019, 11, 619-637. [CrossRef]

18. Jacobs, A.; Warda, A.S.; Verbeek, J.; Cassiman, D.; Spincemaille, P. An Overview of Mouse Models of Nonalcoholic Steatohepatitis: From Past to Present. Curr. Protoc. Mouse Biol. 2016, 6, 185-200. [CrossRef]

19. Ito, M.; Suzuki, J.; Tsujioka, S.; Sasaki, M.; Gomori, A.; Shirakura, T.; Hirose, H.; Ito, M.; Ishihara, A.; Iwaasa, H.; et al. Longitudinal analysis of murine steatohepatitis model induced by chronic exposure to high-fat diet. Hepatol. Res. 2007, 37, 50-57. [CrossRef]

20. Chen, K.; Ma, J.; Jia, X.; Ai, W.; Ma, Z.; Pan, Q. Advancing the understanding of NAFLD to hepatocellular carcinoma development: From experimental models to humans. Biochim. Biophys. Acta Rev. Cancer 2019, 1871, 117-125. [CrossRef]

21. Vonghia, L.; Ruyssers, N.; Schrijvers, D.; Pelckmans, P.; Michielsen, P.; De Clerck, L.; Ramon, A.; Jirillo, E.; Ebo, D.; De Winter, B.; et al. CD4+ROR gamma t++ and Tregs in a Mouse Model of Diet-Induced Nonalcoholic Steatohepatitis. Mediators Inflamm. 2015, 2015, 239623. [CrossRef] [PubMed] 
22. Chen, Y.H.; Chiu, C.C.; Hung, S.W.; Huang, W.C.; Lee, Y.P.; Liu, J.Y.; Huang, Y.T.; Chen, T.H.; Chuang, H.L. Gnotobiotic mice inoculated with Firmicutes, but not Bacteroidetes, deteriorate nonalcoholic fatty liver disease severity by modulating hepatic lipid metabolism. Nutr. Res. 2019, 69, 20-29. [CrossRef] [PubMed]

23. Raman, M.; Ahmed, I.; Gillevet, P.M.; Probert, C.S.; Ratcliffe, N.M.; Smith, S.; Greenwood, R.; Sikaroodi, M.; Lam, V.; Crotty, P.; et al. Fecal microbiome and volatile organic compound metabolome in obese humans with nonalcoholic fatty liver disease. Clin. Gastroenterol. Hepatol. 2013, 11, 868-875 e861-863. [CrossRef] [PubMed]

24. Matsuzawa, N.; Takamura, T.; Kurita, S.; Misu, H.; Ota, T.; Ando, H.; Yokoyama, M.; Honda, M.; Zen, Y.; Nakanuma, Y.; et al. Lipid-induced oxidative stress causes steatohepatitis in mice fed an atherogenic diet. Hepatology 2007, 46, 1392-1403. [CrossRef] [PubMed]

25. Wouters, K.; van Gorp, P.J.; Bieghs, V.; Gijbels, M.J.; Duimel, H.; Lutjohann, D.; Kerksiek, A.; van Kruchten, R.; Maeda, N.; Staels, B.; et al. Dietary cholesterol, rather than liver steatosis, leads to hepatic inflammation in hyperlipidemic mouse models of nonalcoholic steatohepatitis. Hepatology 2008, 48, 474-486. [CrossRef] [PubMed]

26. Wouters, K.; van Bilsen, M.; van Gorp, P.J.; Bieghs, V.; Lutjohann, D.; Kerksiek, A.; Staels, B.; Hofker, M.H.; Shiri-Sverdlov, R. Intrahepatic cholesterol influences progression, inhibition and reversal of non-alcoholic steatohepatitis in hyperlipidemic mice. FEBS Lett. 2010, 584, 1001-1005. [CrossRef]

27. Zheng, S.; Hoos, L.; Cook, J.; Tetzloff, G.; Davis, H., Jr.; van Heek, M.; Hwa, J.J. Ezetimibe improves high fat and cholesterol diet-induced non-alcoholic fatty liver disease in mice. Eur. J. Pharmacol. 2008, 584, 118-124. [CrossRef]

28. Clapper, J.R.; Hendricks, M.D.; Gu, G.; Wittmer, C.; Dolman, C.S.; Herich, J.; Athanacio, J.; Villescaz, C.; Ghosh, S.S.; Heilig, J.S.; et al. Diet-induced mouse model of fatty liver disease and nonalcoholic steatohepatitis reflecting clinical disease progression and methods of assessment. Am. J. Physiol. Gastrointest Liver Physiol. 2013, 305, G483-G495. [CrossRef]

29. Kristiansen, M.N.; Veidal, S.S.; Rigbolt, K.T.; Tolbol, K.S.; Roth, J.D.; Jelsing, J.; Vrang, N.; Feigh, M. Obese diet-induced mouse models of nonalcoholic steatohepatitis-tracking disease by liver biopsy. World J. Hepatol. 2016, 8, 673-684. [CrossRef]

30. Larter, C.Z.; Yeh, M.M. Animal models of NASH: Getting both pathology and metabolic context right. J. Gastroenterol. Hepatol. 2008, 23, 1635-1648. [CrossRef]

31. Leclercq, I.A.; Farrell, G.C.; Schriemer, R.; Robertson, G.R. Leptin is essential for the hepatic fibrogenic response to chronic liver injury. J. Hepatol. 2002, 37, 206-213. [CrossRef]

32. US. Food Drug Administration. Final Determination Regarding Partially Hydrogenated Oils (Removing Trans Fat). Available online: https:/www.federalregister.gov/documents/2018/05/21/2018-10714/finaldetermination-regarding-partially-hydrogenated-oils (accessed on 21 May 2018).

33. Boland, M.L.; Oro, D.; Tolbol, K.S.; Thrane, S.T.; Nielsen, J.C.; Cohen, T.S.; Tabor, D.E.; Fernandes, F.; Tovchigrechko, A.; Veidal, S.S.; et al. Towards a standard diet-induced and biopsy-confirmed mouse model of non-alcoholic steatohepatitis: Impact of dietary fat source. World J. Gastroenterol. 2019, 25, 4904-4920. [CrossRef] [PubMed]

34. Abe, N.; Kato, S.; Tsuchida, T.; Sugimoto, K.; Saito, R.; Verschuren, L.; Kleemann, R.; Oka, K. Longitudinal characterization of diet-induced genetic murine models of non-alcoholic steatohepatitis with metabolic, histological, and transcriptomic hallmarks of human patients. Biol. Open 2019, 8. [CrossRef] [PubMed]

35. Kennedy, A.J.; Ellacott, K.L.; King, V.L.; Hasty, A.H. Mouse models of the metabolic syndrome. Dis. Model. Mech. 2010, 3, 156-166. [CrossRef]

36. Suto, J.; Matsuura, S.; Imamura, K.; Yamanaka, H.; Sekikawa, K. Genetic analysis of non-insulin-dependent diabetes mellitus in KK and KK-Ay mice. Eur. J. Endocrinol. 1998, 139, 654-661. [CrossRef] [PubMed]

37. Henkel, J.; Coleman, C.D.; Schraplau, A.; Jhrens, K.; Weber, D.; Castro, J.P.; Hugo, M.; Schulz, T.J.; Kramer, S.; Schurmann, A.; et al. Induction of steatohepatitis (NASH) with insulin resistance in wildtype B6 mice by a western-type diet containing soybean oil and cholesterol. Mol. Med. 2017, 23, 70-82. [CrossRef]

38. Subramanian, S.; Goodspeed, L.; Wang, S.; Kim, J.; Zeng, L.; Ioannou, G.N.; Haigh, W.G.; Yeh, M.M.; Kowdley, K.V.; O’Brien, K.D.; et al. Dietary cholesterol exacerbates hepatic steatosis and inflammation in obese LDL receptor-deficient mice. J. Lipid Res. 2011, 52, 1626-1635. [CrossRef] 
39. Mari, M.; Caballero, F.; Colell, A.; Morales, A.; Caballeria, J.; Fernandez, A.; Enrich, C.; Fernandez-Checa, J.C.; Garcia-Ruiz, C. Mitochondrial free cholesterol loading sensitizes to TNF- and Fas-mediated steatohepatitis. Cell Metab. 2006, 4, 185-198. [CrossRef]

40. Savard, C.; Tartaglione, E.V.; Kuver, R.; Haigh, W.G.; Farrell, G.C.; Subramanian, S.; Chait, A.; Yeh, M.M.; Quinn, L.S.; Ioannou, G.N. Synergistic interaction of dietary cholesterol and dietary fat in inducing experimental steatohepatitis. Hepatology 2013, 57, 81-92. [CrossRef]

41. Montandon, S.A.; Somm, E.; Loizides-Mangold, U.; de Vito, C.; Dibner, C.; Jornayvaz, F.R. Multi-technique comparison of atherogenic and MCD NASH models highlights changes in sphingolipid metabolism. Sci. Rep. 2019, 9, 16810. [CrossRef]

42. Larter, C.Z.; Yeh, M.M.; Haigh, W.G.; Williams, J.; Brown, S.; Bell-Anderson, K.S.; Lee, S.P.; Farrell, G.C. Hepatic free fatty acids accumulate in experimental steatohepatitis: Role of adaptive pathways. J. Hepatol. 2008, 48, 638-647. [CrossRef] [PubMed]

43. Weltman, M.D.; Farrell, G.C.; Liddle, C. Increased hepatocyte CYP2E1 expression in a rat nutritional model of hepatic steatosis with inflammation. Gastroenterology 1996, 111, 1645-1653. [CrossRef]

44. Fan, Y.; Zhang, W.; Wei, H.; Sun, R.; Tian, Z.; Chen, Y. Hepatic NK cells attenuate fibrosis progression of non-alcoholic steatohepatitis in dependent of CXCL10-mediated recruitment. Liver Int. 2019. [CrossRef] [PubMed]

45. Sahai, A.; Malladi, P.; Pan, X.; Paul, R.; Melin-Aldana, H.; Green, R.M.; Whitington, P.F. Obese and diabetic $\mathrm{db} / \mathrm{db}$ mice develop marked liver fibrosis in a model of nonalcoholic steatohepatitis: Role of short-form leptin receptors and osteopontin. Am. J. Physiol. Gastrointest Liver Physiol. 2004, 287, G1035-G1043. [CrossRef]

46. Sahai, A.; Malladi, P.; Melin-Aldana, H.; Green, R.M.; Whitington, P.F. Upregulation of osteopontin expression is involved in the development of nonalcoholic steatohepatitis in a dietary murine model. Am. J. Physiol. Gastrointest Liver Physiol. 2004, 287, G264-G273. [CrossRef]

47. Itagaki, H.; Shimizu, K.; Morikawa, S.; Ogawa, K.; Ezaki, T. Morphological and functional characterization of non-alcoholic fatty liver disease induced by a methionine-choline-deficient diet in C57BL/6 mice. Int. J. Clin. Exp. Pathol. 2013, 6, 2683-2696.

48. Raubenheimer, P.J.; Nyirenda, M.J.; Walker, B.R. A choline-deficient diet exacerbates fatty liver but attenuates insulin resistance and glucose intolerance in mice fed a high-fat diet. Diabetes 2006, 55, 2015-2020. [CrossRef]

49. Ikejima, K.; Okumura, K.; Lang, T.; Honda, H.; Abe, W.; Yamashina, S.; Enomoto, N.; Takei, Y.; Sato, N. The role of leptin in progression of non-alcoholic fatty liver disease. Hepatol. Res. 2005, 33, 151-154. [CrossRef]

50. Hummel, K.P.; Dickie, M.M.; Coleman, D.L. Diabetes, a new mutation in the mouse. Science 1966, 153, 1127-1128. [CrossRef]

51. Trevaskis, J.L.; Griffin, P.S.; Wittmer, C.; Neuschwander-Tetri, B.A.; Brunt, E.M.; Dolman, C.S.; Erickson, M.R.; Napora, J.; Parkes, D.G.; Roth, J.D. Glucagon-like peptide-1 receptor agonism improves metabolic, biochemical, and histopathological indices of nonalcoholic steatohepatitis in mice. Am. J. Physiol. Gastrointest Liver Physiol. 2012, 302, G762-G772. [CrossRef]

52. Rinella, M.E.; Green, R.M. The methionine-choline deficient dietary model of steatohepatitis does not exhibit insulin resistance. J. Hepatol. 2004, 40, 47-51. [CrossRef] [PubMed]

53. Al Rajabi, A.; Castro, G.S.; da Silva, R.P.; Nelson, R.C.; Thiesen, A.; Vannucchi, H.; Vine, D.F.; Proctor, S.D.; Field, C.J.; Curtis, J.M.; et al. Choline supplementation protects against liver damage by normalizing cholesterol metabolism in Pemt/Ldlr knockout mice fed a high-fat diet. J. Nutr. 2014, 144, 252-257. [CrossRef] [PubMed]

54. Matsumoto, M.; Hada, N.; Sakamaki, Y.; Uno, A.; Shiga, T.; Tanaka, C.; Ito, T.; Katsume, A.; Sudoh, M. An improved mouse model that rapidly develops fibrosis in non-alcoholic steatohepatitis. Int. J. Exp. Pathol. 2013, 94, 93-103. [CrossRef] [PubMed]

55. Miura, K.; Kodama, Y.; Inokuchi, S.; Schnabl, B.; Aoyama, T.; Ohnishi, H.; Olefsky, J.M.; Brenner, D.A.; Seki, E. Toll-like receptor 9 promotes steatohepatitis by induction of interleukin-1beta in mice. Gastroenterology 2010, 139, 323-334.e327. [CrossRef] [PubMed]

56. Tetri, L.H.; Basaranoglu, M.; Brunt, E.M.; Yerian, L.M.; Neuschwander-Tetri, B.A. Severe NAFLD with hepatic necroinflammatory changes in mice fed trans fats and a high-fructose corn syrup equivalent. Am. J. Physiol. Gastrointest Liver Physiol. 2008, 295, G987-G995. [CrossRef] [PubMed] 
57. Tsuchida, T.; Lee, Y.A.; Fujiwara, N.; Ybanez, M.; Allen, B.; Martins, S.; Fiel, M.I.; Goossens, N.; Chou, H.I.; Hoshida, Y.; et al. A simple diet- and chemical-induced murine NASH model with rapid progression of steatohepatitis, fibrosis and liver cancer. J. Hepatol. 2018, 69, 385-395. [CrossRef] [PubMed]

58. Asgharpour, A.; Cazanave, S.C.; Pacana, T.; Seneshaw, M.; Vincent, R.; Banini, B.A.; Kumar, D.P.; Daita, K.; Min, H.K.; Mirshahi, F.; et al. A diet-induced animal model of non-alcoholic fatty liver disease and hepatocellular cancer. J. Hepatol. 2016, 65, 579-588. [CrossRef]

59. Neff, E.P. Farewell, FATZO: A NASH mouse update. Lab. Anim. (NY) 2019, 48, 151. [CrossRef]

60. Alexander, J.; Chang, G.Q.; Dourmashkin, J.T.; Leibowitz, S.F. Distinct phenotypes of obesity-prone AKR/J, DBA2J and C57BL/6J mice compared to control strains. Int. J. Obes. (Lond.) 2006, 30, 50-59. [CrossRef]

61. Peterson, R.G.; Jackson, C.V.; Zimmerman, K.M.; Alsina-Fernandez, J.; Michael, M.D.; Emmerson, P.J.; Coskun, T. Glucose dysregulation and response to common anti-diabetic agents in the FATZO/Pco mouse. PLoS ONE 2017, 12, e0179856. [CrossRef]

62. Sun, G.; Jackson, C.V.; Zimmerman, K.; Zhang, L.K.; Finnearty, C.M.; Sandusky, G.E.; Zhang, G.; Peterson, R.G.; Wang, Y.J. The FATZO mouse, a next generation model of type 2 diabetes, develops NAFLD and NASH when fed a Western diet supplemented with fructose. BMC Gastroenterol. 2019, 19, 41. [CrossRef] [PubMed]

63. Bieghs, V.; Van Gorp, P.J.; Wouters, K.; Hendrikx, T.; Gijbels, M.J.; van Bilsen, M.; Bakker, J.; Binder, C.J.; Lutjohann, D.; Staels, B.; et al. LDL receptor knock-out mice are a physiological model particularly vulnerable to study the onset of inflammation in non-alcoholic fatty liver disease. PLoS ONE 2012, 7, e30668. [CrossRef] [PubMed]

64. Schierwagen, R.; Maybuchen, L.; Zimmer, S.; Hittatiya, K.; Back, C.; Klein, S.; Uschner, F.E.; Reul, W.; Boor, P.; Nickenig, G.; et al. Seven weeks of Western diet in apolipoprotein-E-deficient mice induce metabolic syndrome and non-alcoholic steatohepatitis with liver fibrosis. Sci. Rep. 2015, 5, 12931. [CrossRef] [PubMed]

65. Henkel, J.; Coleman, C.D.; Schraplau, A.; Johrens, K.; Weiss, T.S.; Jonas, W.; Schurmann, A.; Puschel, G.P. Augmented liver inflammation in a microsomal prostaglandin E synthase 1 (mPGES-1)-deficient diet-induced mouse NASH model. Sci. Rep. 2018, 8, 16127. [CrossRef]

66. Horrillo, R.; Planaguma, A.; Gonzalez-Periz, A.; Ferre, N.; Titos, E.; Miquel, R.; Lopez-Parra, M.; Masferrer, J.L.; Arroyo, V.; Claria, J. Comparative protection against liver inflammation and fibrosis by a selective cyclooxygenase-2 inhibitor and a nonredox-type 5-lipoxygenase inhibitor. J. Pharmacol. Exp. Ther. 2007, 323, 778-786. [CrossRef]

67. Karck, U.; Peters, T.; Decker, K. The release of tumor necrosis factor from endotoxin-stimulated rat Kupffer cells is regulated by prostaglandin E2 and dexamethasone. J. Hepatol. 1988, 7, 352-361. [CrossRef]

68. Park, J.Y.; Pillinger, M.H.; Abramson, S.B. Prostaglandin E2 synthesis and secretion: The role of PGE2 synthases. Clin. Immunol. 2006, 119, 229-240. [CrossRef]

69. Anstee, Q.M.; Day, C.P. The Genetics of Nonalcoholic Fatty Liver Disease: Spotlight on PNPLA3 and TM6SF2. Semin. Liver Dis. 2015, 35, 270-290. [CrossRef]

70. Romeo, S.; Kozlitina, J.; Xing, C.; Pertsemlidis, A.; Cox, D.; Pennacchio, L.A.; Boerwinkle, E.; Cohen, J.C.; Hobbs, H.H. Genetic variation in PNPLA3 confers susceptibility to nonalcoholic fatty liver disease. Nat. Genet. 2008, 40, 1461-1465. [CrossRef]

71. Pingitore, P.; Romeo, S. The role of PNPLA3 in health and disease. Biochim. Biophys. Acta Mol. Cell Biol. Lipids 2019, 1864, 900-906. [CrossRef]

72. Smagris, E.; BasuRay, S.; Li, J.; Huang, Y.; Lai, K.M.; Gromada, J.; Cohen, J.C.; Hobbs, H.H. Pnpla3I148M knockin mice accumulate PNPLA3 on lipid droplets and develop hepatic steatosis. Hepatology 2015, 61, 108-118. [CrossRef] [PubMed]

73. Chen, X.; Zhou, P.; De, L.; Li, B.; Su, S. The roles of transmembrane 6 superfamily member 2 rs58542926 polymorphism in chronic liver disease: A meta-analysis of 24,147 subjects. Mol. Genet. Genomic Med. 2019, 7, e824. [CrossRef] [PubMed]

74. Kozlitina, J.; Smagris, E.; Stender, S.; Nordestgaard, B.G.; Zhou, H.H.; Tybjaerg-Hansen, A.; Vogt, T.F.; Hobbs, H.H.; Cohen, J.C. Exome-wide association study identifies a TM6SF2 variant that confers susceptibility to nonalcoholic fatty liver disease. Nat. Genet. 2014, 46, 352-356. [CrossRef] [PubMed]

75. Cast, A.; Kumbaji, M.; D’Souza, A.; Rodriguez, K.; Gupta, A.; Karns, R.; Timchenko, L.; Timchenko, N. Liver Proliferation Is an Essential Driver of Fibrosis in Mouse Models of Nonalcoholic Fatty Liver Disease. Hepatol. Commun. 2019, 3, 1036-1049. [CrossRef] 
76. Qian, Y.W.; Chen, Y.; Yang, W.; Fu, J.; Cao, J.; Ren, Y.B.; Zhu, J.J.; Su, B.; Luo, T.; Zhao, X.F.; et al. p28(GANK) prevents degradation of Oct4 and promotes expansion of tumor-initiating cells in hepatocarcinogenesis. Gastroenterology 2012, 142, 1547-1558.e1514. [CrossRef]

77. Arsov, T.; Silva, D.G.; O’Bryan, M.K.; Sainsbury, A.; Lee, N.J.; Kennedy, C.; Manji, S.S.; Nelms, K.; Liu, C.; Vinuesa, C.G.; et al. Fat aussie-A new Alstrom syndrome mouse showing a critical role for ALMS1 in obesity, diabetes, and spermatogenesis. Mol. Endocrinol. 2006, 20, 1610-1622. [CrossRef]

78. Collin, G.B.; Marshall, J.D.; Ikeda, A.; So, W.V.; Russell-Eggitt, I.; Maffei, P.; Beck, S.; Boerkoel, C.F.; Sicolo, N.; Martin, M.; et al. Mutations in ALMS1 cause obesity, type 2 diabetes and neurosensory degeneration in Alstrom syndrome. Nat. Genet. 2002, 31, 74-78. [CrossRef]

79. Soga, M.; Kishimoto, Y.; kawaguchi, J.; Nakai, Y.; Kawamura, Y.; Inagaki, S.; Katoh, K.; Oohara, T.; Makino, S.; Oshima, I. The FLS mouse: A new inbred strain with spontaneous fatty liver. Lab. Anim. Sci. 1999, 49, 269-275.

80. Semba, T.; Nishimura, M.; Nishimura, S.; Ohara, O.; Ishige, T.; Ohno, S.; Nonaka, K.; Sogawa, K.; Satoh, M.; Sawai, S.; et al. The FLS (fatty liver Shionogi) mouse reveals local expressions of lipocalin-2, CXCL1 and CXCL9 in the liver with non-alcoholic steatohepatitis. BMC Gastroenterol. 2013, 13, 120. [CrossRef]

81. Sugihara, T.; Koda, M.; Kishina, M.; Kato, J.; Tokunaga, S.; Matono, T.; Ueki, M.; Murawaki, Y. Fatty liver Shionogi-ob/ob mouse: A new candidate for a non-alcoholic steatohepatitis model. Hepatol. Res. 2013, 43, 547-556. [CrossRef]

82. He, L.; Tian, D.A.; Li, P.Y.; He, X.X. Mouse models of liver cancer: Progress and recommendations. Oncotarget 2015, 6, 23306-23322. [CrossRef] [PubMed]

83. Watanabe, S.; Horie, Y.; Kataoka, E.; Sato, W.; Dohmen, T.; Ohshima, S.; Goto, T.; Suzuki, A. Non-alcoholic steatohepatitis and hepatocellular carcinoma: Lessons from hepatocyte-specific phosphatase and tensin homolog (PTEN)-deficient mice. J. Gastroenterol. Hepatol. 2007, 22 (Suppl. 1), S96-S100. [CrossRef]

84. Takakura, K.; Oikawa, T.; Tomita, Y.; Mizuno, Y.; Nakano, M.; Saeki, C.; Torisu, Y.; Saruta, M. Mouse models for investigating the underlying mechanisms of nonalcoholic steatohepatitis-derived hepatocellular carcinoma. World J. Gastroenterol. 2018, 24, 1989-1994. [CrossRef] [PubMed]

85. Chen, C.Y.; Chen, J.; He, L.; Stiles, B.L. PTEN: Tumor Suppressor and Metabolic Regulator. Front. Endocrinol. (Lausanne) 2018, 9, 338. [CrossRef] [PubMed]

86. Gandhi, C.R.; Chaillet, J.R.; Nalesnik, M.A.; Kumar, S.; Dangi, A.; Demetris, A.J.; Ferrell, R.; Wu, T.; Divanovic, S.; Stankeiwicz, T.; et al. Liver-specific deletion of augmenter of liver regeneration accelerates development of steatohepatitis and hepatocellular carcinoma in mice. Gastroenterology 2015, 148, 379-391.e374. [CrossRef] [PubMed]

87. Francavilla, A.; Vujanovic, N.L.; Polimeno, L.; Azzarone, A.; Iacobellis, A.; Deleo, A.; Hagiya, M.; Whiteside, T.L.; Starzl, T.E. The in vivo effect of hepatotrophic factors augmenter of liver regeneration, hepatocyte growth factor, and insulin-like growth factor-II on liver natural killer cell functions. Hepatology 1997, 25, 411-415. [CrossRef]

88. Ibrahim, S.; Weiss, T.S. Augmenter of liver regeneration: Essential for growth and beyond. Cytokine Growth Factor Rev. 2019, 45, 65-80. [CrossRef]

89. Gandhi, C.R.; Murase, N.; Starzl, T.E. Cholera toxin-sensitive GTP-binding protein-coupled activation of augmenter of liver regeneration (ALR) receptor and its function in rat kupffer cells. J. Cell Physiol. 2010, 222, 365-373. [CrossRef]

90. Itoh, M.; Suganami, T.; Nakagawa, N.; Tanaka, M.; Yamamoto, Y.; Kamei, Y.; Terai, S.; Sakaida, I.; Ogawa, Y. Melanocortin 4 receptor-deficient mice as a novel mouse model of nonalcoholic steatohepatitis. Am. J. Pathol. 2011, 179, 2454-2463. [CrossRef]

91. Yamada, T.; Kashiwagi, Y.; Rokugawa, T.; Kato, H.; Konishi, H.; Hamada, T.; Nagai, R.; Masago, Y.; Itoh, M.; Suganami, T.; et al. Evaluation of hepatic function using dynamic contrast-enhanced magnetic resonance imaging in melanocortin 4 receptor-deficient mice as a model of nonalcoholic steatohepatitis. Magn. Reson. Imaging 2019, 57, 210-217. [CrossRef]

92. Denk, H.; Abuja, P.M.; Zatloukal, K. Animal models of NAFLD from the pathologist's point of view. Biochim. Biophys. Acta Mol. Basis Dis. 2019, 1865, 929-942. [CrossRef]

93. Nishida, T.; Tsuneyama, K.; Fujimoto, M.; Nomoto, K.; Hayashi, S.; Miwa, S.; Nakajima, T.; Nakanishi, Y.; Sasaki, Y.; Suzuki, W.; et al. Spontaneous onset of nonalcoholic steatohepatitis and hepatocellular carcinoma in a mouse model of metabolic syndrome. Lab. Invest. 2013, 93, 230-241. [CrossRef] [PubMed] 
94. Bettermann, K.; Mehta, A.K.; Hofer, E.M.; Wohlrab, C.; Golob-Schwarzl, N.; Svendova, V.; Schimek, M.G.; Stumptner, C.; Thuringer, A.; Speicher, M.R.; et al. Keratin 18-deficiency results in steatohepatitis and liver tumors in old mice: A model of steatohepatitis-associated liver carcinogenesis. Oncotarget 2016, 7, 73309-73322. [CrossRef] [PubMed]

95. Luedde, T.; Beraza, N.; Kotsikoris, V.; van Loo, G.; Nenci, A.; De Vos, R.; Roskams, T.; Trautwein, C.; Pasparakis, M. Deletion of NEMO/IKKgamma in liver parenchymal cells causes steatohepatitis and hepatocellular carcinoma. Cancer Cell 2007, 11, 119-132. [CrossRef] [PubMed]

96. Cano, A.; Buque, X.; Martinez-Una, M.; Aurrekoetxea, I.; Menor, A.; Garcia-Rodriguez, J.L.; Lu, S.C.; Martinez-Chantar, M.L.; Mato, J.M.; Ochoa, B.; et al. Methionine adenosyltransferase 1A gene deletion disrupts hepatic very low-density lipoprotein assembly in mice. Hepatology 2011, 54, 1975-1986. [CrossRef]

97. Domitrovic, R.; Jakovac, H.; Tomac, J.; Sain, I. Liver fibrosis in mice induced by carbon tetrachloride and its reversion by luteolin. Toxicol. Appl. Pharmacol. 2009, 241, 311-321. [CrossRef]

98. Sharma, L.; Gupta, D.; Abdullah, S.T. Thioacetamide potentiates high cholesterol and high fat diet induced steato-hepatitic changes in livers of C57BL/6J mice: A novel eight weeks model of fibrosing NASH. Toxicol. Lett. 2019, 304, 21-29. [CrossRef]

99. Fujii, M.; Shibazaki, Y.; Wakamatsu, K.; Honda, Y.; Kawauchi, Y.; Suzuki, K.; Arumugam, S.; Watanabe, K.; Ichida, T.; Asakura, H.; et al. A murine model for non-alcoholic steatohepatitis showing evidence of association between diabetes and hepatocellular carcinoma. Med. Mol. Morphol 2013, 46, 141-152. [CrossRef]

100. Jena, P.K.; Sheng, L.; Liu, H.X.; Kalanetra, K.M.; Mirsoian, A.; Murphy, W.J.; French, S.W.; Krishnan, V.V.; Mills, D.A.; Wan, Y.Y. Western Diet-Induced Dysbiosis in Farnesoid X Receptor Knockout Mice Causes Persistent Hepatic Inflammation after Antibiotic Treatment. Am. J. Pathol. 2017, 187, 1800-1813. [CrossRef]

101. Norheim, F.; Hui, S.T.; Kulahcioglu, E.; Mehrabian, M.; Cantor, R.M.; Pan, C.; Parks, B.W.; Lusis, A.J. Genetic and hormonal control of hepatic steatosis in female and male mice. J. Lipid Res. 2017, 58, 178-187. [CrossRef]

102. Lonardo, A.; Nascimbeni, F.; Ballestri, S.; Fairweather, D.; Win, S.; Than, T.A.; Abdelmalek, M.F.; Suzuki, A. Sex Differences in Nonalcoholic Fatty Liver Disease: State of the Art and Identification of Research Gaps. Hepatology 2019, 70, 1457-1469. [CrossRef] [PubMed]

103. Spruss, A.; Henkel, J.; Kanuri, G.; Blank, D.; Puschel, G.P.; Bischoff, S.C.; Bergheim, I. Female mice are more susceptible to nonalcoholic fatty liver disease: Sex-specific regulation of the hepatic AMP-activated protein kinase-plasminogen activator inhibitor 1 cascade, but not the hepatic endotoxin response. Mol. Med. 2012, 18, 1346-1355. [CrossRef] [PubMed]

104. Marin, V.; Rosso, N.; Dal Ben, M.; Raseni, A.; Boschelle, M.; Degrassi, C.; Nemeckova, I.; Nachtigal, P.; Avellini, C.; Tiribelli, C.; et al. An Animal Model for the Juvenile Non-Alcoholic Fatty Liver Disease and Non-Alcoholic Steatohepatitis. PLoS ONE 2016, 11, e0158817. [CrossRef] [PubMed]

105. Zhou, L.; Liu, D.; Wang, Z.; Dong, H.; Xu, X.; Zhou, S. Establishment and Comparison of Juvenile Female Mouse Models of Nonalcoholic Fatty Liver Disease and Nonalcoholic Steatohepatitis. Gastroenterol. Res. Pract. 2018, 2018, 8929620. [CrossRef] [PubMed]

106. Giles, D.A.; Moreno-Fernandez, M.E.; Stankiewicz, T.E.; Graspeuntner, S.; Cappelletti, M.; Wu, D.; Mukherjee, R.; Chan, C.C.; Lawson, M.J.; Klarquist, J.; et al. Thermoneutral housing exacerbates nonalcoholic fatty liver disease in mice and allows for sex-independent disease modeling. Nat. Med. 2017, 23, 829-838. [CrossRef] [PubMed]

107. Adamovich, Y.; Rousso-Noori, L.; Zwighaft, Z.; Neufeld-Cohen, A.; Golik, M.; Kraut-Cohen, J.; Wang, M.; Han, X.; Asher, G. Circadian clocks and feeding time regulate the oscillations and levels of hepatic triglycerides. Cell Metab. 2014, 19, 319-330. [CrossRef]

108. Jacobi, D.; Liu, S.; Burkewitz, K.; Kory, N.; Knudsen, N.H.; Alexander, R.K.; Unluturk, U.; Li, X.; Kong, X.; Hyde, A.L.; et al. Hepatic Bmal1 Regulates Rhythmic Mitochondrial Dynamics and Promotes Metabolic Fitness. Cell Metab. 2015, 22, 709-720. [CrossRef]

109. Kettner, N.M.; Voicu, H.; Finegold, M.J.; Coarfa, C.; Sreekumar, A.; Putluri, N.; Katchy, C.A.; Lee, C.; Moore, D.D.; Fu, L. Circadian Homeostasis of Liver Metabolism Suppresses Hepatocarcinogenesis. Cancer Cell 2016, 30, 909-924. [CrossRef]

110. Baker, M. 1,500 scientists lift the lid on reproducibility. Nature 2016, 533, 452-454. [CrossRef]

111. Begley, C.G.; Ellis, L.M. Drug development: Raise standards for preclinical cancer research. Nature 2012, 483, 531-533. [CrossRef] 
112. Goodman, S.N.; Fanelli, D.; Ioannidis, J.P. What does research reproducibility mean? Sci. Transl. Med. 2016, 8, 341ps312. [CrossRef] [PubMed]

113. Zou, Y.; Li, J.; Lu, C.; Wang, J.; Ge, J.; Huang, Y.; Zhang, L.; Wang, Y. High-fat emulsion-induced rat model of nonalcoholic steatohepatitis. Life Sci. 2006, 79, 1100-1107. [CrossRef] [PubMed]

114. Kucera, O.; Cervinkova, Z. Experimental models of non-alcoholic fatty liver disease in rats. World J. Gastroenterol. 2014, 20, 8364-8376. [CrossRef] [PubMed]

115. Rodrigues, A.A.; Andrade, R.S.B.; Vasconcelos, D.F.P. Relationship between Experimental Diet in Rats and Nonalcoholic Hepatic Disease: Review of Literature. Int. J. Hepatol. 2018, 2018, 9023027. [CrossRef]

116. Maciejewska, D.; Lukomska, A.; Dec, K.; Skonieczna-Zydecka, K.; Gutowska, I.; Skorka-Majewicz, M.; Styburski, D.; Misiakiewicz-Has, K.; Pilutin, A.; Palma, J.; et al. Diet-Induced Rat Model of Gradual Development of Non-Alcoholic Fatty Liver Disease (NAFLD) with Lipopolysaccharides (LPS) Secretion. Diagnostics (Basel) 2019, 9, 205. [CrossRef]

117. Khurana, P.; Yadati, T.; Goyal, S.; Dolas, A.; Houben, T.; Oligschlaeger, Y.; Agarwal, A.K.; Kulkarni, A.; Shiri-Sverdlov, R. Inhibiting Extracellular Cathepsin D Reduces Hepatic Steatosis in Sprague(-)Dawley Rats (dagger). Biomolecules 2019, 9, 171. [CrossRef]

118. Maeso-Diaz, R.; Boyer-Diaz, Z.; Lozano, J.J.; Ortega-Ribera, M.; Peralta, C.; Bosch, J.; Gracia-Sancho, J. New Rat Model of Advanced NASH Mimicking Pathophysiological Features and Transcriptomic Signature of The Human Disease. Cells 2019, 8, 1062. [CrossRef]

119. Carmiel-Haggai, M.; Cederbaum, A.I.; Nieto, N. A high-fat diet leads to the progression of non-alcoholic fatty liver disease in obese rats. FASEB J. 2005, 19, 136-138. [CrossRef]

120. Lieber, C.S.; Leo, M.A.; Mak, K.M.; Xu, Y.; Cao, Q.; Ren, C.; Ponomarenko, A.; DeCarli, L.M. Model of nonalcoholic steatohepatitis. Am. J. Clin. Nutr. 2004, 79, 502-509. [CrossRef]

121. Kirsch, R.; Clarkson, V.; Shephard, E.G.; Marais, D.A.; Jaffer, M.A.; Woodburne, V.E.; Kirsch, R.E.; Hall Pde, L. Rodent nutritional model of non-alcoholic steatohepatitis: Species, strain and sex difference studies. J. Gastroenterol. Hepatol. 2003, 18, 1272-1282. [CrossRef]

122. Domitrovic, R.; Jakovac, H.; Milin, C.; Radosevic-Stasic, B. Dose- and time-dependent effects of luteolin on carbon tetrachloride-induced hepatotoxicity in mice. Exp. Toxicol. Pathol. 2009, 61, 581-589. [CrossRef]

123. Walenbergh, S.M.; Houben, T.; Rensen, S.S.; Bieghs, V.; Hendrikx, T.; van Gorp, P.J.; Oligschlaeger, Y.; Jeurissen, M.L.; Gijbels, M.J.; Buurman, W.A.; et al. Plasma cathepsin D correlates with histological classifications of fatty liver disease in adults and responds to intervention. Sci. Rep. 2016, 6, 38278. [CrossRef]

124. Houben, T.; Oligschlaeger, Y.; Hendrikx, T.; Bitorina, A.V.; Walenbergh, S.M.A.; van Gorp, P.J.; Gijbels, M.J.J.; Friedrichs, S.; Plat, J.; Schaap, F.G.; et al. Cathepsin D regulates lipid metabolism in murine steatohepatitis. Sci. Rep. 2017, 7, 3494. [CrossRef]

125. Gehrke, N.; Biedenbach, J.; Huber, Y.; Straub, B.K.; Galle, P.R.; Simon, P.; Schattenberg, J.M. Voluntary exercise in mice fed an obesogenic diet alters the hepatic immune phenotype and improves metabolic parameters-An animal model of life style intervention in NAFLD. Sci. Rep. 2019, 9, 4007. [CrossRef] [PubMed]

126. Kawanishi, N.; Niihara, H.; Mizokami, T.; Yada, K.; Suzuki, K. Exercise training attenuates neutrophil infiltration and elastase expression in adipose tissue of high-fat-diet-induced obese mice. Physiol. Rep. 2015, 3. [CrossRef] [PubMed]

127. Boeckmans, J.; Natale, A.; Rombaut, M.; Buyl, K.; Rogiers, V.; De Kock, J.; Vanhaecke, T.; R, M.R. Anti-NASH Drug Development Hitches a Lift on PPAR Agonism. Cells 2019, 9, 37. [CrossRef] [PubMed]

128. Francque, S.; Verrijken, A.; Caron, S.; Prawitt, J.; Paumelle, R.; Derudas, B.; Lefebvre, P.; Taskinen, M.R.; Van Hul, W.; Mertens, I.; et al. PPARalpha gene expression correlates with severity and histological treatment response in patients with non-alcoholic steatohepatitis. J. Hepatol. 2015, 63, 164-173. [CrossRef] [PubMed]

129. Shipman, K.E.; Strange, R.C.; Ramachandran, S. Use of fibrates in the metabolic syndrome: A review. World J. Diabetes 2016, 7, 74-88. [CrossRef] [PubMed]

130. Ishibashi, S.; Arai, H.; Yokote, K.; Araki, E.; Suganami, H.; Yamashita, S.; Group, K.S. Efficacy and safety of pemafibrate (K-877), a selective peroxisome proliferator-activated receptor alpha modulator, in patients with dyslipidemia: Results from a 24-week, randomized, double blind, active-controlled, phase 3 trial. J. Clin. Lipidol. 2018, 12, 173-184. [CrossRef] 
131. Honda, Y.; Kessoku, T.; Ogawa, Y.; Tomeno, W.; Imajo, K.; Fujita, K.; Yoneda, M.; Takizawa, T.; Saito, S.; Nagashima, Y.; et al. Pemafibrate, a novel selective peroxisome proliferator-activated receptor alpha modulator, improves the pathogenesis in a rodent model of nonalcoholic steatohepatitis. Sci. Rep. 2017, 7, 42477. [CrossRef]

132. Bays, H.E.; Schwartz, S.; Littlejohn, T., 3rd; Kerzner, B.; Krauss, R.M.; Karpf, D.B.; Choi, Y.J.; Wang, X.; Naim, S.; Roberts, B.K. MBX-8025, a novel peroxisome proliferator receptor-delta agonist: Lipid and other metabolic effects in dyslipidemic overweight patients treated with and without atorvastatin. J. Clin. Endocrinol. Metab 2011, 96, 2889-2897. [CrossRef] [PubMed]

133. Haczeyni, F.; Wang, H.; Barn, V.; Mridha, A.R.; Yeh, M.M.; Haigh, W.G.; Ioannou, G.N.; Choi, Y.J.; McWherter, C.A.; Teoh, N.C.; et al. The selective peroxisome proliferator-activated receptor-delta agonist seladelpar reverses nonalcoholic steatohepatitis pathology by abrogating lipotoxicity in diabetic obese mice. Hepatol. Commun. 2017, 1, 663-674. [CrossRef] [PubMed]

134. Lee, Y.H.; Kim, J.H.; Kim, S.R.; Jin, H.Y.; Rhee, E.J.; Cho, Y.M.; Lee, B.W. Lobeglitazone, a Novel Thiazolidinedione, Improves Non-Alcoholic Fatty Liver Disease in Type 2 Diabetes: Its Efficacy and Predictive Factors Related to Responsiveness. J. Korean Med. Sci. 2017, 32, 60-69. [CrossRef] [PubMed]

135. Choung, S.; Joung, K.H.; You, B.R.; Park, S.K.; Kim, H.J.; Ku, B.J. Treatment with Lobeglitazone Attenuates Hepatic Steatosis in Diet-Induced Obese Mice. PPAR Res. 2018, 2018, 4292509. [CrossRef] [PubMed]

136. Ratziu, V.; Harrison, S.A.; Francque, S.; Bedossa, P.; Lehert, P.; Serfaty, L.; Romero-Gomez, M.; Boursier, J.; Abdelmalek, M.; Caldwell, S.; et al. Elafibranor, an Agonist of the Peroxisome Proliferator-Activated Receptor-alpha and -delta, Induces Resolution of Nonalcoholic Steatohepatitis Without Fibrosis Worsening. Gastroenterology 2016, 150, 1147-1159.e1145. [CrossRef] [PubMed]

137. Tolbol, K.S.; Kristiansen, M.N.; Hansen, H.H.; Veidal, S.S.; Rigbolt, K.T.; Gillum, M.P.; Jelsing, J.; Vrang, N.; Feigh, M. Metabolic and hepatic effects of liraglutide, obeticholic acid and elafibranor in diet-induced obese mouse models of biopsy-confirmed nonalcoholic steatohepatitis. World J. Gastroenterol. 2018, 24, 179-194. [CrossRef]

138. Alukal, J.J.; Thuluvath, P.J. Reversal of NASH fibrosis with pharmacotherapy. Hepatol. Int. 2019, 13, 534-545. [CrossRef]

139. Roth, J.D.; Veidal, S.S.; Fensholdt, L.K.D.; Rigbolt, K.T.G.; Papazyan, R.; Nielsen, J.C.; Feigh, M.; Vrang, N.; Young, M.; Jelsing, J.; et al. Combined obeticholic acid and elafibranor treatment promotes additive liver histological improvements in a diet-induced ob/ob mouse model of biopsy-confirmed NASH. Sci. Rep. 2019, 9, 9046. [CrossRef]

140. Hui, S.T.; Kurt, Z.; Tuominen, I.; Norheim, F.; R, C.D.; Pan, C.; Dirks, D.L.; Magyar, C.E.; French, S.W.; Chella Krishnan, K.; et al. The Genetic Architecture of Diet-Induced Hepatic Fibrosis in Mice. Hepatology 2018, 68, 2182-2196. [CrossRef]

(C) 2020 by the authors. Licensee MDPI, Basel, Switzerland. This article is an open access article distributed under the terms and conditions of the Creative Commons Attribution (CC BY) license (http://creativecommons.org/licenses/by/4.0/). 